\title{
Update on the Cetacean Fauna of the Mediterranean Levantine Basin
}

\author{
D. Kerem ${ }^{*}, 1$, N. Hadar ${ }^{1}$, O. Goffman ${ }^{1}$, A. Scheinin ${ }^{1}$, R. Kent ${ }^{1}$, O. Boisseau ${ }^{2}$ and U. Schattner ${ }^{3}$ \\ ${ }^{1}$ Israel Marine Mammal Research and Assistance Center, Institute for Maritime Studies, Charney School of Marine \\ Sciences, University of Haifa, Haifa, Israel \\ ${ }^{2}$ International Fund for Animal Welfare, London, England \\ ${ }^{3}$ Department of Marine Geosciences, Charney School of Marine Sciences, University of Haifa, Haifa Israel
}

\begin{abstract}
The Levantine Basin (LB) is still considered a void as regards its cetacean fauna: species population abundance and distribution patterns are unknown, and even the list of species and their regional status have so far not been finalized. In an effort to fill the knowledge gap, we present original data collected in the LB over the years 1993-2009. The data relies on strandings, bycatch victims and on incidental and dedicated-survey sightings. We supplement these by reviewing available information on cetacean occurrence in the LB, prior to and including the above period. We believe that the following list and suggested status is a comprehensive updated regional inventory: Species with a 'regular' status include the common bottlenose dolphin, striped dolphin, common dolphin, Risso's dolphin and rough-toothed dolphin, as well as Cuvier's beaked whale; 'visitors' include false killer whale, sperm whale, minke whale and fin whale; Indo-Pacific humpback dolphin, humpback whale and killer whale are designated 'vagrants'. The only common Mediterranean species notably absent is the long-finned pilot whale. Indeed, despite its profound oligotrophicity, the diversity of cetacean species in the LB equals that in the western basins, and due to the relatively lower anthropogenic impact that it sustains, it should receive its share of resources and efforts towards conserving this diversity.
\end{abstract}

Keywords: Cetacea, mediterranean sea, levantine basin, stranding and sighting data, regional status.

\section{INTRODUCTION}

Information on the occurrence and distribution of cetacean species in the Mediterranean is non-homogenous. While the longstanding extensive research of countries on the European coast produced substantial published data for the Alboran, Ligurian, Tirrhenian, Adriatic, Ionian and Aegean basins, very little is known about Levantine and North African waters [1]. These regions hold particular interest, as in addition to species prevalent in the Mediterranean as a whole, they are more likely to be inhabited or visited by Lessepsian migrants from the Red Sea [2]. While geophysicists ascribe the term 'Levantine Basin' (LB) to the southeastern-most corner of the Mediterranean, within the confines of the Israeli and Egyptian shorelines, Cyprus and Eratosthenes Sea Mount [3], in this report we chose to use this term for a wider geographical division, namely: the part of the Mediterranean east of an imaginary line connecting the westernmost point of Crete and the northernmost point of Cyrenaica on the Libyan coast, excluding the Aegean Sea and the eastern horn of the Hellenic Trench (Fig. 1). The latter are excluded mainly on the grounds of their cetacean fauna being rather extensively researched and reported on within the bounds of the Greek Seas [4].

Seemingly, the saline, warm and ultra-oligotrophic LB holds little promise for sustaining an abundance and a

*Address correspondence to this author at the Israel Marine Mammal Research and Assistance Center, Institute for Maritime Studies, Charney School of Marine Sciences, University of Haifa, Haifa, Israel;

Tel: +972-4-8249449; Fax: +972-4-8240493;

E-mail: dankerem@research.haifa.ac.il diverse assemblage of top predators. Salinity levels of the Levantine Surface Water exceed $38.95 \%$ due to the combined effect of high evaporation and low runoff. Mixing of the water column reaches $\sim 150 \mathrm{~m}$ during winter. During the rest of the year surface temperature may reach $30^{\circ} \mathrm{C}$ and the mixing is restricted to the upper $\sim 25 \mathrm{~m}$, overlaying a sharp thermocline and halocline. During most of the year, nutrient values are extremely low and primary productivity levels are around 41-49 $\mathrm{g} \mathrm{C} \mathrm{m}^{-2} \mathrm{y}^{-1}[5,6]$. Throughout geologic and recent history, the Nile River has been the main natural source of sediments and nutrients reaching the southeastern Mediterranean. The supply declined considerably following the construction and deployment of the Aswan High Dam in 1964 [7]. This anthropogenic intervention compromised regional marine primary production and its supported foodweb [7] and, after a 3-year delay, caused hydrological and ecological effects that reached the westernmost bounds of the Mediterranean [8].

The Mediterranean coast of Israel extends $180 \mathrm{~km}$ in a nearly straight line, trending NE - NNE. The continental shelf narrows from $25-30 \mathrm{~km}$ wide off northeastern Sinai to less than $10 \mathrm{~km}$ off Rosh HaNikrah, on the border with Lebanon [9] (Fig. 2). Sand dominates a strip 2.5 to $4 \mathrm{~km}$ wide, extending from the beach to $15-25 \mathrm{~m}$ depth. At greater depths the sands are increasingly diluted by silt and clay. Despite the dam, a limited amount of Nile derived siliciclastic sediments are deposited into the Mediterranean, where they are transported towards the Israeli coasts by counterclockwise wind-induced longshore currents. As the siliciclastics in the sediments fall off, they are replaced nearshore by autochthonous carbonate sands and at the northern end of the Nile litoral cell, off Akko, biogenic 


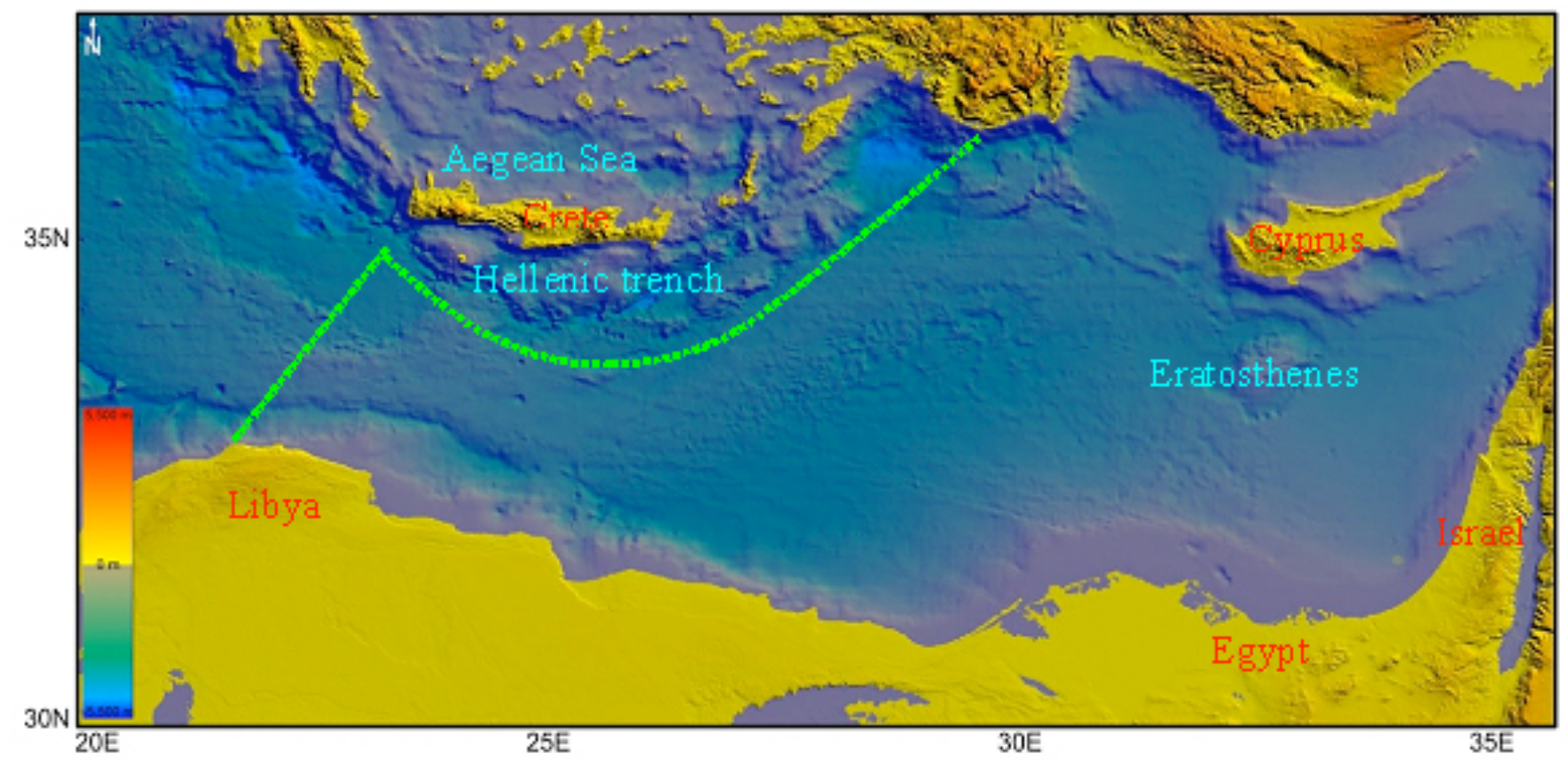

Fig. (1). The Levantine Basin as defined in this report, bounded by the dotted green line and the Mediterranean shores to its east.

carbonate sediments prevail [10]. In fact, Haifa Bay (Fig. 2) marks the boundary between the 'Nilotic' and the 'Levantine' benthic provinces, amply demonstrated by distinct assemblages of foraminifers [11].

In this report we summarize the current knowledge about cetacean presence and distribution in the LB, updating our preliminary communication [12]. Information is based mainly on sighting and stranding data collected between 1993-2009 by the Israeli Marine Mammal Research \& Assistance Center (IMMRAC). The final compilation of observations indicates that all species regularly occurring in the Mediterranean, as well as those considered visitors, are also found in the LB. The only exceptions are the longfinned pilot whale (Globicephala melas, Traill 1809) that, to our knowledge, has not been documented in the region and the killer whale (Orcinus orca, Linnaeus 1758), which maintains a small sub-population restricted to the Gibraltar Strait [1].

\section{MATERIALS AND METHODS}

\section{Data Sources}

Four sources of information were considered reliable for identifying species:

1. Stranded specimens and animals incidentally caught by various types of fishing gear, which were identified by IMMRAC researchers. When external form and color patterns were insufficient for definite identification, skull morphology was used. In particular, presence of deep palatal/maxillary grooves was used to distinguish short-beaked common dolphin (Delphinus delphis) from striped dolphin (Stenella coeruleoalba) [13]. In one instance of a headless, badly decomposed baleen whale - identity of fin whale (Balaenoptera physalus) was ascertained by
DNA fingerprinting (L.A. Pastene, Institute of Cetacean Research, Tokyo). Stranding events are reported to IMMRAC's $24 \mathrm{~h}$ on-call national network, which operates under a renewable annual permit from the Israeli Nature \& Parks Authority. Wardens from the latter organization report their own encounters as well as channel reports from the public. Other major official reporting sources include: lifeguards, officers of the Marine \& Coastal Pollution Dept. of the Ministry of Environmental Protection and beach sanitary workers. Public awareness has steadily increased to a point where we believe nearly all cetacean beachings on the Israeli Mediterranean coastline are reported and documented.

2. Open sea sightings and acoustic detections by IMMRAC researchers, opportunistic as well as during dedicated surveys carried out across the Israeli continental shelf and slope. Of the latter, acoustic detection of sperm whale (Physeter macrocephalus) clicks, were obtained during a 5 day, $1000 \mathrm{~km}$ long, acoustic survey conducted in June 2005 aboard a sailing yacht. Detections were made using a HP30-ST stereo towed hydrophone brought to Israel and deployed by Vasilis Podiadis, who also verified the identification. In addition, during three weeks in September of 2005, Eco-Oceans' $20 \mathrm{~m}$ long $\mathrm{R} \backslash \mathrm{V}$ 'Mediterranean Explorer' was chartered for a survey covering a total of $1,320 \mathrm{~km}$, over an area of 9,240 $\mathrm{km}^{2}$ along and across the Israeli continental shelf. The surveying track comprised of 12 "saw-tooth" shaped transects, oriented in a cross-shore direction, with a base $14 \mathrm{~km}$ wide which extended $55 \mathrm{~km}$ offshore, to roughly over the 1,200 $\mathrm{m}$ water depth contour (Fig. 2). Each transect was traversed during one day, at an average cruising speed of 8 knots, with the boat docking for the night. Visual searching was employed during daylight hours, in Beaufort sea states $\leq 3$, by 


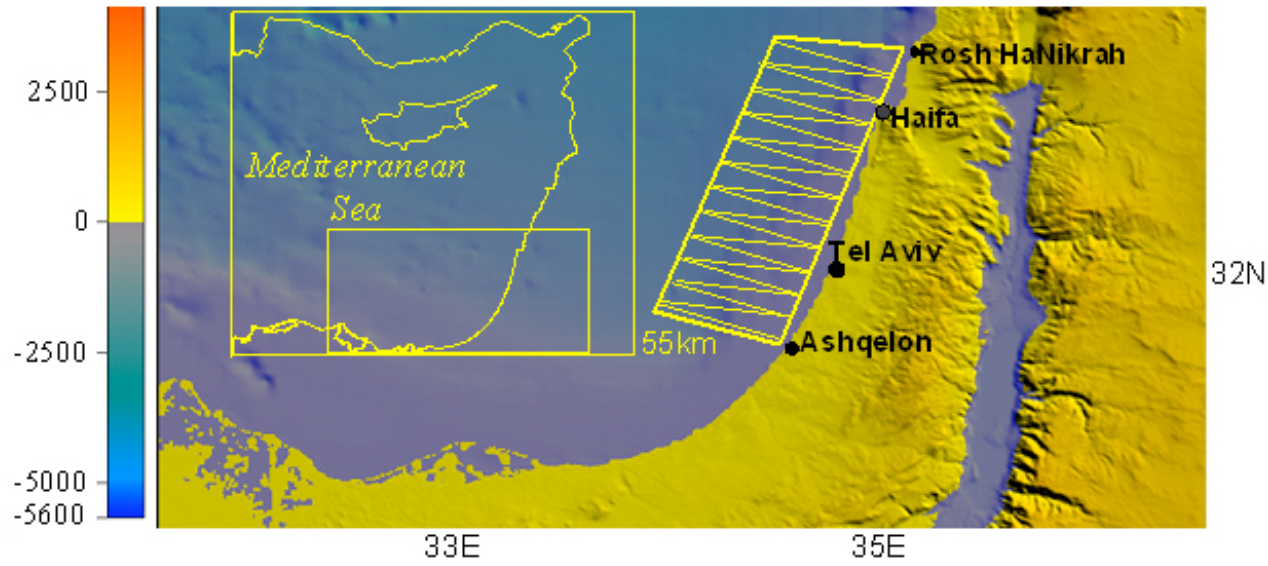

Fig. (2). Outline of the September 2005 line transect along the Israeli coast, from Rosh Hanikrah, on the border with Lebanon in the north to Ashqelon, near the border of theGaza strip in the South. Each 'saw-tooth' was covered in one day before docking for the night.

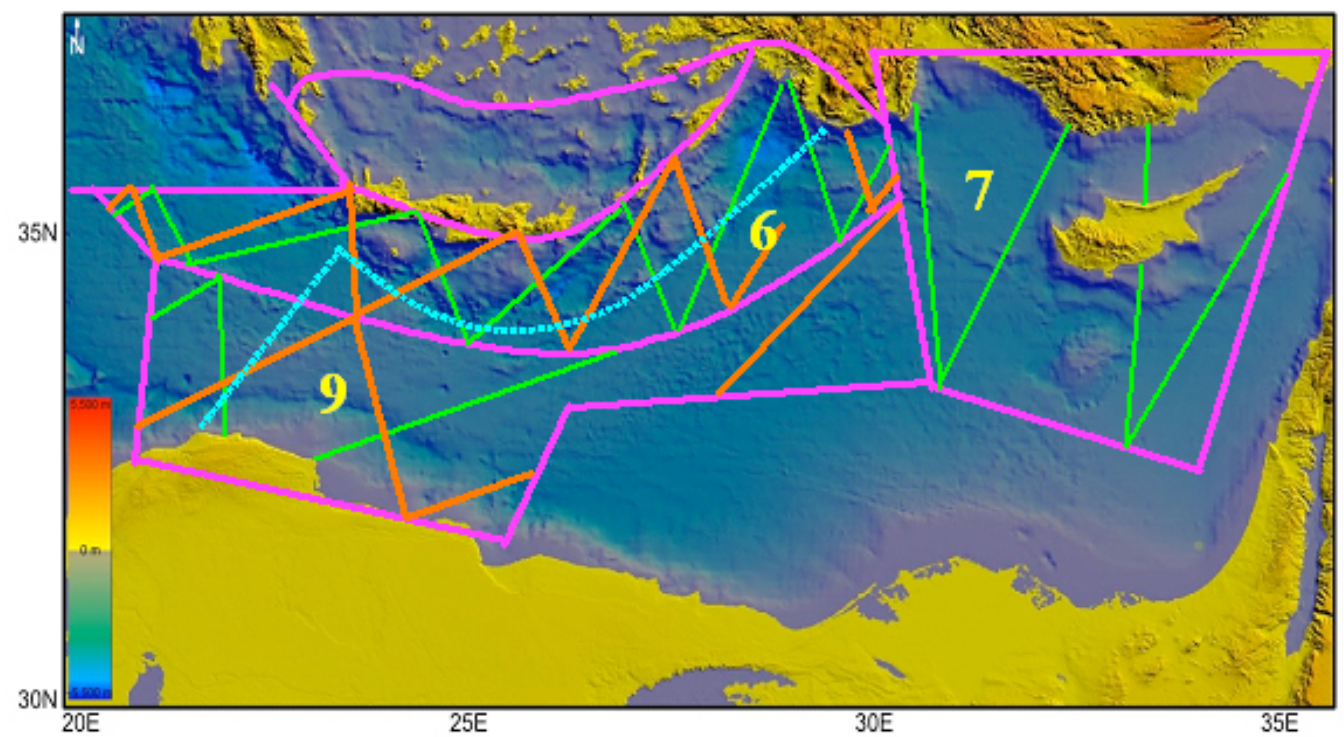

Fig. (3). Portions of the Mediterranean-wide survey track of the R $\backslash \mathrm{V}$ 'Song of the Whale' within the bounds of the Levantine Basin (LB), traversed during May-September of 2007. Purple lines delimit the survey blocks, the relevant ones being 6, 7 \& 9: 'Crete Trench', 'Cyprus' and 'Eastern Basin', respectively. Green and orange lines are westward and eastward transect lines and the turquois dotted line is the western bound of the LB, as defined in this report.

alternating $2-3 \mathrm{~h}$ shifts of three observers each. Searching followed the 'distance sampling' mode [14], with the vessel adhering to the transect line without attempting to approach distantly detected groups. One observer (tracker) equipped with binoculars scanned a $60^{\circ}$ central arc atop a platform $2.5 \mathrm{~m}$ above sea level and two observers positioned on the cabin roof (4.6 m above sea level) scanned $90^{\circ}$ to port and starboard, respectively. The latter used the naked eye to search and binoculars to confirm sightings, identify species and count animals ${ }^{1}$.

3. Opportunistic sightings by non-expert Israeli observers (navy, yachtsmen, port authorities, coastal police and marine construction crews), that were either

1 Kent R, Scheinin A, Kerem D. Preliminary results of the first dedicated multi-day cetacean survey over the Israeli Mediterranean continental shelf and adjacent waters. Abstract. $3^{\text {rd }}$ Annual Conference of the Israeli Association for Aquatic Sciences. Haifa, May 23, 2006 backed by photographs or indisputably accredited through careful interrogation by IMMRAC experts in real time and/or soon after the sighting, aided by a pictorial guide.

4. First-hand visual sightings and acoustic detections collected aboard the $21 \mathrm{~m}$ long $\mathrm{R} / \mathrm{V}$ 'Song of the Whale' as part of the 2003-2007 Mediterranean-wide survey conducted by the research team of the International Fund for Animal Welfare (IFAW). This survey too was conducted in a 'distance sampling' mode, with detailed information on survey means and methods given in [15]. The relevant search blocks to this report were all of block 7 ('Cyprus'), the greater part of block 9 ('Eastern Basin') and part of block 6 ('Crete Trench'), transected during May-September 2007 (Fig. 3), with a cumulative transect distance of $2,540 \mathrm{~km}$. 


\section{Statistical Analysis}

Following normality tests (Kolmogorov-Smirnov), and tests for homogeneity of variances (Levene), the significance of body length and group size differences were tested by unpaired t-tests and ANOVA, or two-sample and k-sample nonparametric tests, as appropriate. Differences were considered statistically significant when $\mathrm{P}$ was $\leq 0.05$.

\section{RESULTS}

Observations sorted by frequency of species encounters (strandings + sightings) are presented below in the following order: strandings, sightings by IMMRAC staff, sightings by other Israeli parties and sightings by the R/V 'song of the whale' team. Stranding data for all species are listed in Table 1 and mapped in Figs. (4-6). Details on sightings in Israeli waters (roughly out to $25 \mathrm{~km}$ from shore) and across the LB are summarized in Table $\mathbf{2}$ and Fig. (7) and in Table $\mathbf{3}$ and Fig. (8), respectively.

\section{Common Bottlenose Dolphin (Tursiops truncatus, Montagu 1821)}

This is by far the most frequently encountered species in Israeli waters throughout the year and along the entire coastline. At sea it makes $85 \%$ of all reported sightings and $60 \%$ of beachings. These observations include newborns and calves of all ages. The majority of sightings were close to shore (within a six mile strip). However the September 2005 transect survey identified some sightings over the continental slope, in water $>1000 \mathrm{~m}$. Given its abundance, this species is amenable to systematic research and longitudinal studies, the details of which will be published separately.

\section{Striped Dolphin (Stenella coeruleoalba, Meyen 1833)}

\section{Strandings}

During the period covered by this report, 14 single strandings were recorded, five of which involved live individuals, and one stranding of two animals. Strandings occurred year round and along the entire coastline; all age groups except newborns were represented.

\section{Sightings by IMMRAC}

Sighted only twice by IMMRAC researchers: once during the September 2005 line-transect survey, $22 \mathrm{~km}$ off Nahariya and once by A.S. on a private sail en route from Cyprus to Haifa.

\section{Sightings by Other Israeli Parties}

There were eight second-hand local sightings, one of a mixed group with short-beaked common dolphin. Mean group size \pm SD was $18 \pm 17$ (range: $2-50$ ) and water depth ranged from 12 to $1500 \mathrm{~m}$.

\section{Sightings by $R / V$ 'Song of the Whale' Team}

The team logged 12 sightings of striped dolphin across the LB, with estimated group sizes ranging from 2-60. Two of the groups included calves, one calf each.

The resultant combined mean \pm SD school size of LB sightings $(\mathrm{N}=22)$ was $16.9 \pm 15.8$ (range $2-60)$. The median group size value of 6 in Israeli coastal waters was not significantly different than that of 13 in LB-wide deep waters, Mann-Whitney U Test; $\mathrm{p}=0.357$.

\section{Short-Beaked Common Dolphin (Delphinus delphis, Linnaeus 1758)}

\section{Strandings}

Three single mature individuals beached during the reported period.

\section{Sightings by IMMRAC}

Two group sightings were made by A.S.: one of 30 individuals including six calves, $50 \mathrm{~km}$ west of Gaza on August of 2007 and one of 7 adults, $9 \mathrm{~km}$ off Netanya, on July of 2009. Another group of 40-50 individuals including five calves and a newborn was sighted by N.H. in May of 2009, $5 \mathrm{~km}$ off Ashdod. Two sightings of single animals were also made, one of which was documented by O.G. in a mixed group with common bottlenose dolphin, in the wake of a bottom-trawler.

\section{Sightings by Other Israeli Parties}

Additional 15 authenticated second-party sightings were logged in Israeli waters and off Gaza, all of them close to shore. Sightings off Israel are rare during winter (DecemberFebruary) and north of Tel Aviv. During the last five years, large $(>20)$ groups are regularly reported opposite the southern part of the coast (Fig. 6).

Mean group size \pm SD was 22.2 \pm 19.1 (range 1-75). Median group size of 3 in the period 1993-2004 was significantly smaller than that of 30 in the period 2005-2009, Mann-Whitney U Test; $\mathrm{p}<0.001$.

\section{Striped-or-Common Dolphin \\ Sightings by Other Israeli Parties}

Virtually all experienced trawl-boat skippers readily distinguish between the "regular" large grey stout-beaked dolphins (common bottlenose dolphin) and the less frequent small, black or bi-colored and slender-beaked dolphins (either striped or common dolphin, usually without being able to distinguish the two). We have logged 185 alleged striped-or-common dolphin (as opposed to 1550 common bottlenose dolphin) second-party sightings in the reported period. However, since these sightings are not speciesspecific, they are excluded from the current report.

\section{Risso's Dolphin (Grampus griseus, G. Cuvier 1812)}

\section{Strandings}

Six strandings of this species were recorded, three of which involved live individuals. One of the latter apparently involved a mother-calf pair.

\section{Sightings by IMMRAC}

A group of 20-25 individuals, including calves, was observed during the sperm whale acoustic survey of June 2005, $22 \mathrm{~km}$ northwest of Haifa. Another group was observed during along the line-transect survey of September 
10 The Open Marine Biology Journal, 2012, Volume 6

Table 1. List of Cetacean (Other than Common Bottlenose Dolphin) Strandings on the Israeli Coast: 1993-2009

\begin{tabular}{|c|c|c|c|c|c|}
\hline Species & Date & Locale & Gender & Age- Group & Remarks \\
\hline $\mathrm{Sc}$ & $21 / 06 / 1994$ & Ashdod & M & A & Stranded live \\
\hline $\mathrm{Sc}$ & $11 / 09 / 1994$ & Haifa & M & $\mathrm{J}$ & \\
\hline $\mathrm{Sc}$ & $05 / 01 / 1995$ & Atlit & $?$ & $\mathrm{~J}$ & \\
\hline $\mathrm{Sc}$ & $23 / 08 / 1995$ & Caesarea & M & $\mathrm{C}$ & \\
\hline $\mathrm{Sc}$ & $23 / 12 / 1996$ & Netanya & M & A & \\
\hline $\mathrm{Sc}$ & $14 / 10 / 2000$ & Atlit & $\mathrm{F}$ & A & \\
\hline $\mathrm{Sc}$ & $29 / 04 / 2001$ & Ashqelon & $\mathrm{F}$ & A & \\
\hline $\mathrm{Sc}$ & $15 / 06 / 2002$ & Palmahim & $\mathrm{F}$ & $\mathrm{J}$ & Entangled in gill net \\
\hline $\mathrm{Sc}$ & $27 / 02 / 2003$ & Ziqim & $2 \mathrm{~F}$ & $\mathrm{~A} ; \mathrm{J}$ & \\
\hline $\mathrm{Sc}$ & $01 / 04 / 2003$ & Nahariya & $\mathrm{F}$ & A & \\
\hline $\mathrm{Sc}$ & $26 / 05 / 2003$ & Acko & $\mathrm{F}$ & $\mathrm{J}$ & Stranded live \\
\hline $\mathrm{Sc}$ & $06 / 09 / 2006$ & Ma'ayan Zvi & M & A & Entangled in gill net \\
\hline $\mathrm{Sc}$ & $25 / 07 / 2008$ & Giv'at Olga & M & $\mathrm{J}$ & Swam near shore days before and stranded live \\
\hline Sc & $30 / 12 / 2008$ & Bat Yam & $\mathrm{F}$ & $\mathrm{J}$ & Stranded live, succumbed after $36 \mathrm{~h}$ \\
\hline Sc & $09 / 01 / 2009$ & Giv'at Olga & M & $\mathrm{C}$ & Stranded live, died after $2 \mathrm{~h}$ \\
\hline $\mathrm{Sb}$ & $16 / 03 / 1997$ & Dugit & M & $\mathrm{C}$ & \\
\hline $\mathrm{Sb}$ & $13 / 04 / 1998$ & Atlit & $\mathrm{F}$ & A & \\
\hline $\mathrm{Sb}$ & $05 / 04 / 2001$ & Nahariya & $\mathrm{F}$ & $\mathrm{C}$ & \\
\hline $\mathrm{Sb}$ & $16 / 02 / 2002$ & Atlit & M & $\mathrm{C}$ & Entangled in gill net \\
\hline $\mathrm{Sb}$ & $09 / 03 / 2003$ & Haifa & $\mathrm{F}$ & $\mathrm{C}$ & Entangled in gill net \\
\hline $\mathrm{Sb}$ & $20 / 03 / 2003$ & Acko & M & $\mathrm{C}$ & \\
\hline $\mathrm{Sb}$ & $15 / 03 / 2006$ & Nahariya & $\mathrm{F}$ & $\mathrm{C}$ & \\
\hline $\mathrm{Sb}$ & $04 / 05 / 2008$ & Netanya & $?$ & $\mathrm{C}$ & \\
\hline $\mathrm{Zc}$ & $18 / 03 / 1999$ & Shavey Zion & $\mathrm{M}$ & A & \\
\hline $\mathrm{Zc}$ & $23 / 06 / 2001$ & Acko & M & $\mathrm{J}$ & \\
\hline $\mathrm{Zc}$ & $17 / 07 / 2002$ & Shefayim & $\mathrm{M}$ & $\mathrm{J}$ & Stranded live \\
\hline $\mathrm{Zc}$ & $20 / 04 / 2004$ & Netanya & M & A & \\
\hline $\mathrm{Zc}$ & $30 / 04 / 2004$ & Haifa & M & A & \\
\hline $\mathrm{Zc}$ & $06 / 04 / 2006$ & Tel Aviv & M & $\mathrm{J}$ & \\
\hline $\mathrm{Zc}$ & $09 / 04 / 2008$ & Haifa & M & $\mathrm{J}$ & \\
\hline Gg & $15 / 05 / 1998$ & Acko & $?$ & $\mathrm{~J}$ & \\
\hline Gg & $16 / 06 / 1998$ & Ma'agan Michael & M & A & \\
\hline $\mathrm{Gg}$ & 08/06/1999 & Shefayim & $\mathrm{F}+?$ & $\mathrm{~A}+\mathrm{J}$ & Stranded live \\
\hline $\mathrm{Gg}$ & $30 / 03 / 2005$ & Herzliya & M & $\mathrm{C}$ & Stranded live \\
\hline $\mathrm{Gg}$ & $40 / 06 / 2006$ & Atlit & $?$ & $\mathrm{C}$ & Beached and refloated twice, not seen again. \\
\hline $\mathrm{Gg}$ & $02 / 10 / 2008$ & Poleg & $?$ & A & Severely decomposed \\
\hline $\mathrm{Bp}$ & $15 / 06 / 2000$ & Haifa & $?$ & $\mathrm{C}$ & Floated into Port \\
\hline $\mathrm{Bp}$ & $11 / 04 / 2005$ & Haifa & M & $\mathrm{C}$ & Entered port \\
\hline $\mathrm{Bp}$ & $15 / 02 / 2007$ & Haifa & M & $\mathrm{C}$ & Floated into Port \\
\hline $\mathrm{Bp}$ & $04 / 02 / 2008$ & Ashqelon & M & $\mathrm{C}$ & Entered anchorage \\
\hline
\end{tabular}


(Table 1) Contd.....

\begin{tabular}{|c|c|c|c|c|c|}
\hline Species & Date & Locale & Gender & Age- Group & Remarks \\
\hline $\mathrm{Ba}$ & $08 / 05 / 2000$ & Acko & M & $\mathrm{C}$ & Entangled in gill net \\
\hline $\mathrm{Ba}$ & $08 / 02 / 2004$ & Haifa & $\mathrm{F}$ & $\mathrm{C}$ & Entangled in gill net \\
\hline $\mathrm{Ba}$ & $01 / 04 / 2006$ & Haifa & $?$ & $\mathrm{C}$ & Severely decomposed \\
\hline $\mathrm{Ba}$ & $13 / 08 / 2006$ & Netanya - Hadera* & $?$ & $\mathrm{C}$ & Lower jaw in trawl-net \\
\hline Dd & $15 / 06 / 1993$ & Haifa & M & A & \\
\hline Dd & $30 / 10 / 2001$ & Michmoret & $\mathrm{F}$ & $\mathrm{J}$ & \\
\hline Dd & $25 / 06 / 2004$ & Ashdod & M & A & \\
\hline $\mathrm{Pm}$ & $13 / 07 / 1996$ & Ashqelon & $?$ & A & Severely decomposed \\
\hline $\mathrm{Pm}$ & 03/08/1999 & Dor & $\mathrm{F}$ & A & Severely decomposed \\
\hline $\mathrm{Pm}$ & $28 / 08 / 2005$ & Hadera & $\mathrm{F}$ & $\mathrm{NB} / \mathrm{F}$ & \\
\hline $\mathrm{Pc}$ & $30 / 06 / 2004$ & Habonim & $?(\mathrm{M})$ & A & Severely decomposed \\
\hline
\end{tabular}

Abbreviations: M-male, F-female, A-adult, J-juvenile, C-calf, F-fetus, *-points of casting and hoisting net. Sc-Stenella coeruleoalba, Sb-Steno bredanensis, Zc-Ziphius cavirostris, Gg-Grampus griseus, Bp-Balaenoptera physalus, Ba-Balaenoptera acutorostrata, Pm-Physeter macrocephalus, Dd-Delphinus delphis, Pc-Psudorca crassidens.

2005, $52 \mathrm{~km}$ off Ashdod. The presence of a very distinctlymarked individual on both occasions could mean that it was the same group.

\section{Sightings by Other Israeli Parties}

There were eight authenticated second-party reports, several of which from yachtsmen traveling back and forth between Israel and Cyprus.

\section{Sightings by the $R / V$ 'Song of the Whale' Team}

A group of 11-15 individuals was spotted about midway between Cyprus and Crete during June of 2007.

We found a non-significant tendency (Mann-Whitney U Test; $p=0.096$ ) for the median group size of 3 for Israeli coastal water sightings $(n=6)$ to be smaller than the median group size of 20 for the more remote and deeper water sightings $(\mathrm{n}=5)$.

\section{Sperm Whale (Physeter macrocephalus, Linnaeus 1758)}

\section{Strandings}

Three single carcasses were investigated, all demonstrating various degrees of decomposition. One of the three was a newborn or a near term fetus. These three beachings occurred during July-August, with a wide spatial spread.

\section{Sightings by IMMRAC}

A group of 10 individuals which included three calves was encountered on July 1997, $20 \mathrm{~km}$ off Larnaca Marina, Cyprus. One acoustic detection of a single individual occurred during the acoustic survey of June 2005, at 19:45, $50 \mathrm{~km}$ off Ashdod.

\section{Sightings by Other Israeli Parties}

Seven sightings by non-experts were reported, most of them accompanied by on-site photographs. All sightings were of single individuals except one, in which two animals were seen. Five of the seven were within Israeli waters, with a depth range of $25-300 \mathrm{~m}$. The other two reports were also of single whales: one was seen off Beirut, Lebanon (coordinates unavailable) on February of 2007 and the other, $110 \mathrm{~km}$ northwest of Haifa, on September 2008.

\section{Sightings by the $R / V$ 'Song of the Whale' Team}

Two detections of single individuals, one in relatively shallow waters off Libya and one over deep water, close to the Crete Trench

\section{Rough-Toothed Dolphin (Steno bredanensis, G. Cuvier in Lesson 1828)}

\section{Strandings}

Eight single strandings, spread along the entire Israeli coast, with seven of the eight being calves under 1 year. The occurrences had a distinct seasonal pattern, by occurring only between February and May.

\section{Sightings by IMMRAC}

One spectacular sighting of ca. 80 individuals on March 22, 2006, inside and on the sea-side of the breakwater of Haifa Port. In addition, four adult individuals were documented by A.S. on June 5, 2007, $75 \mathrm{~km}$ southeast of Cyprus

\section{Sightings by Other Israeli Parties}

Five adult individuals were captured on video bow riding a private yacht at noon of November 15, 2009, $160 \mathrm{~km}$ enroute from Larnaca to Herzliya.

\section{Sightings by the $R / V$ 'Song of the Whale' Team}

Two groups of nine individuals were documented, one on June 17, 2007, north of Cyprus and another, on July $1^{\text {st }} 2007$, off the Cyrenaican coast, at a point located slightly west of the LB as defined here (Fig. 7). 


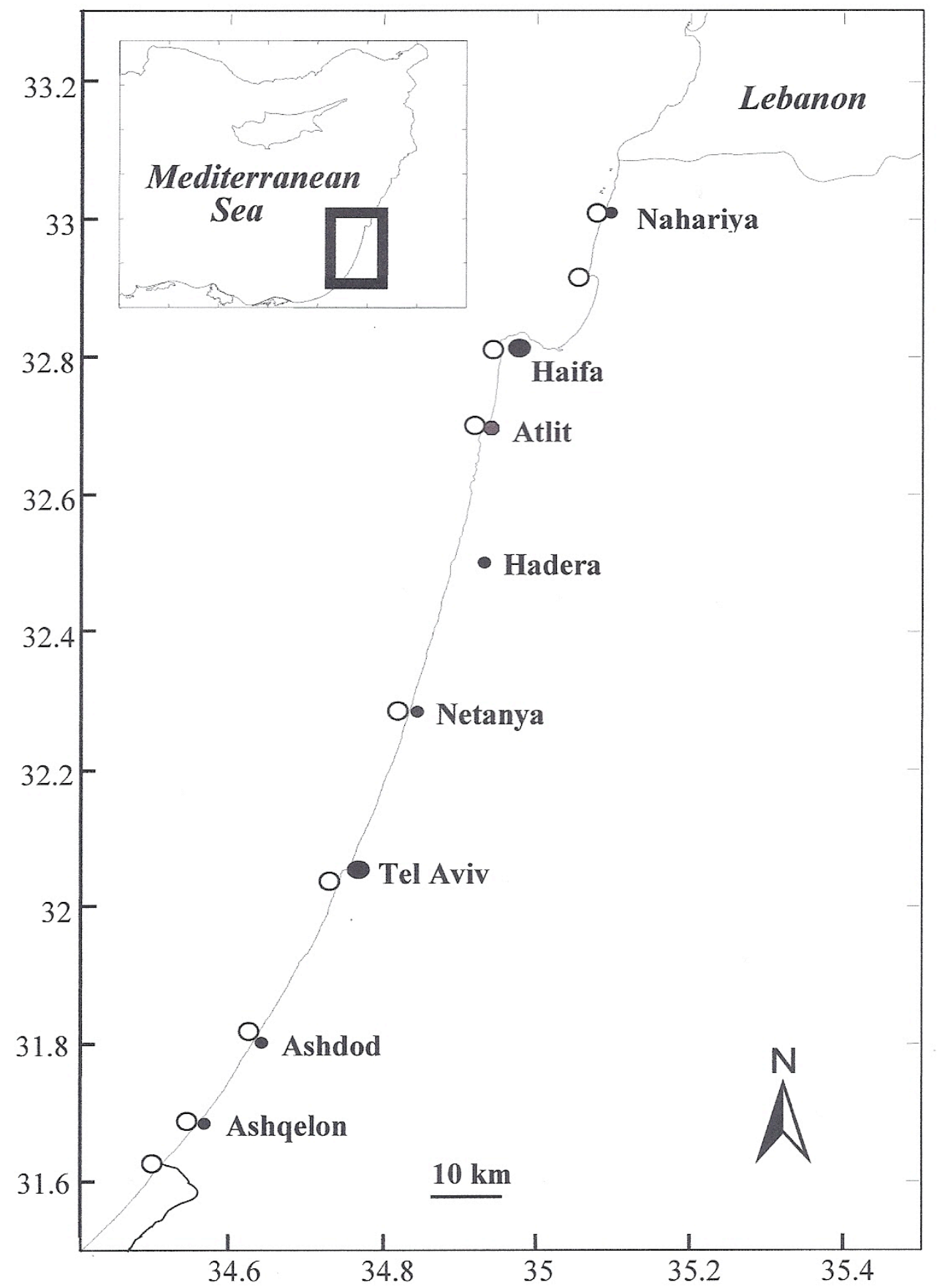

Fig. (4). Stranding sites (white circles) of striped dolphin along the Israeli coastline, 1993-2009.

\section{Common Minke Whale (Balaenoptera acutorostrata, Lacépède 1804)}

\section{Strandings}

Two gill-net calf entanglements were recorded for this species, both investigated soon after death. The first, a $3.5 \mathrm{~m}$ male, was found in the early morning of May 8, 2000 at a water depth of $14 \mathrm{~m}, 3.5 \mathrm{~km}$ off Akko shore. The second victim was a $5 \mathrm{~m}$ female calf, caught on the night of February 3-4, 2004, $1 \mathrm{~km}$ off Carmel coast at a water depth of $12 \mathrm{~m}$. Fresh milk traces in the lower esophagus and forestomach of the male were revealed by endoscopy (Pentax). On autopsy, both calves had milk at various digestive stages along the GI tract, with no evidence of other food intake. Apart from congested lungs, no gross pathology of the musculo-skeletal system or of the internal organs was observed. This was confirmed by histopathology, which showed alveolar flooding consistent with aspiration or lung edema, all other tissue structure being within normal limits. Mitochondrial DNA control region sequencing found the male calf to be related to the north Atlantic stock of common minke whale [16]. Two other calf mortalities of unknown cause were investigated. The first was of a body in advanced state of decay and the second of a right mandible with remnants of soft tissue found in the cod-end of a bottom trawler. 


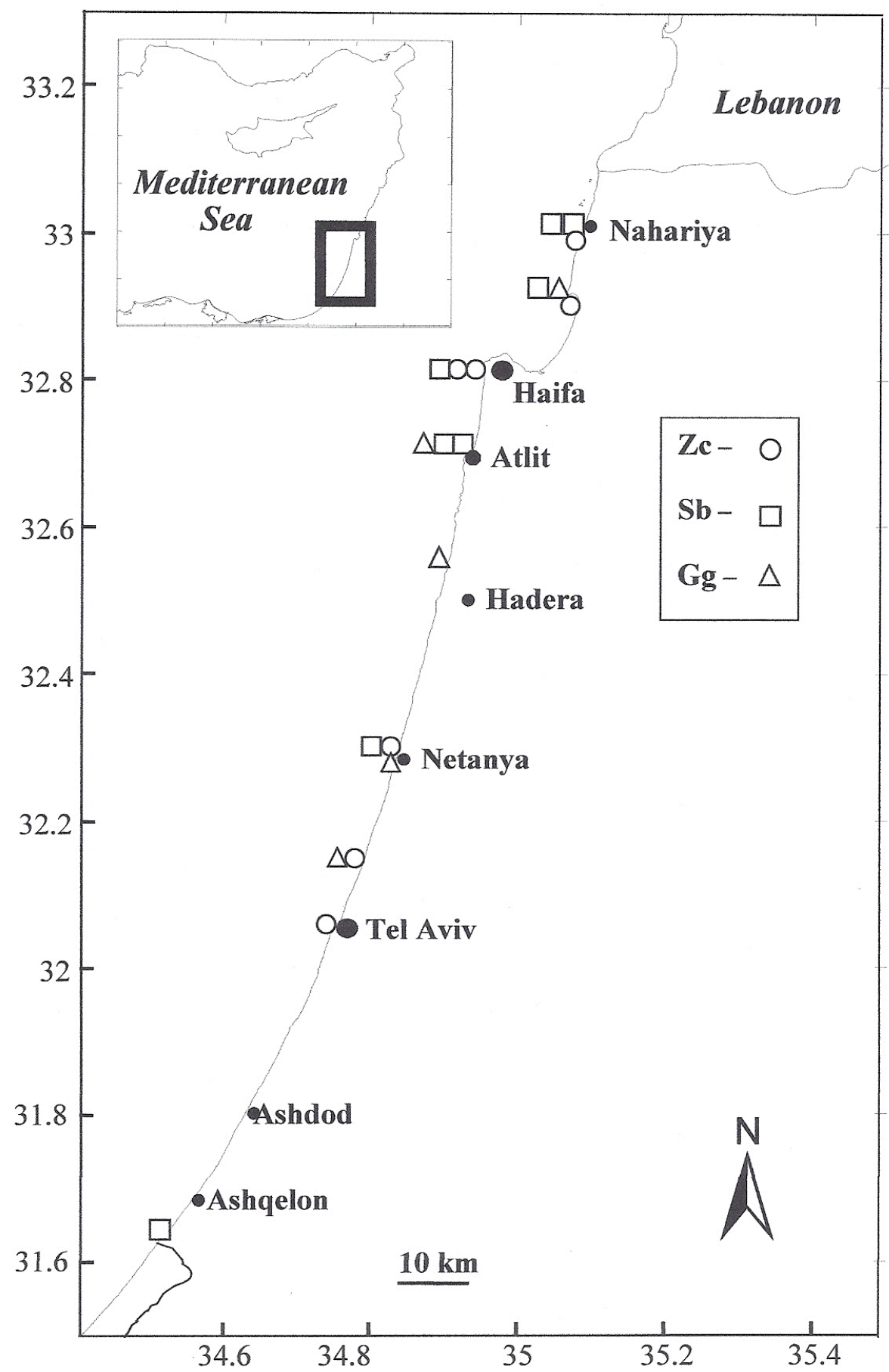

Fig. (5). Stranding sites of Risso's dolphin $(\mathrm{Gg})$, rough-toothed dolphin $(\mathrm{Sb})$ and Cuvier's beaked whale (Zc) along the Israeli coastline, 1993-2009.

\section{Sightings by Other Israeli Parties}

Seven corroborated second party sightings were logged, 6 of single individuals and one of a pair.

\section{Fin Whale (Balaenoptera physalus, Linnaeus 1758)}

\section{Strandings}

During the last decade six separate instances of single young individuals were encountered entering into Israeli harbors, either swimming in alive or floating in dead. The first was a calf, estimated at 11 meters, which floated headless into Haifa Port on June of 2000 in an advanced state of decomposition. Subsequent DNA typing showed it to be a fin whale. The second was a live $7.8 \mathrm{~m}$ young male calf that on April 2005 escorted a Turkish freighter into Haifa port. This individual disappeared for 10 days soon after its arrival and was then found floating dead near the dock. It was extremely emaciated and most probably had starved to death after separating from its mother. The $11.5 \mathrm{~m}$ long, wasted body of another male calf floated into Haifa Port on February of 2007. On February 2008, a 13.4 m long male 
entered alive into the Eilat-Ashqelon Oil-Pipe anchorage in Ashqelon, only to succumb after a few hours. It was not noticeably wasted and apart from a well-healed amputation of half of its right fluke that left propeller scars on the remaining part, it did not show any gross external or internal pathology.

\section{Sightings by IMMRAC}

Two live individuals, both with an estimated body length of ca $10 \mathrm{~m}$, were sighted by IMMRAC staff. One of them was observed by O.G. at twilight of July 26, 2008, inside
Haifa Port. The other, clearly cachectic, was observed by N.H. just outside the entrance to Tel-Aviv marina on the morning of April $3^{\text {rd }}, 2009$. Probably the same individual was re-sighted at 22:00 near a fish-farm inside Ashdod Port.

\section{Sightings by Other Israeli Parties}

Four second party open sea sightings were reported. Three were in Israeli waters: two of single individuals and one of a group of 5 whales, all very close to shore. A single whale was also spotted $55 \mathrm{~km}$ off Gaza over a bottom depth of $600 \mathrm{~m}$.

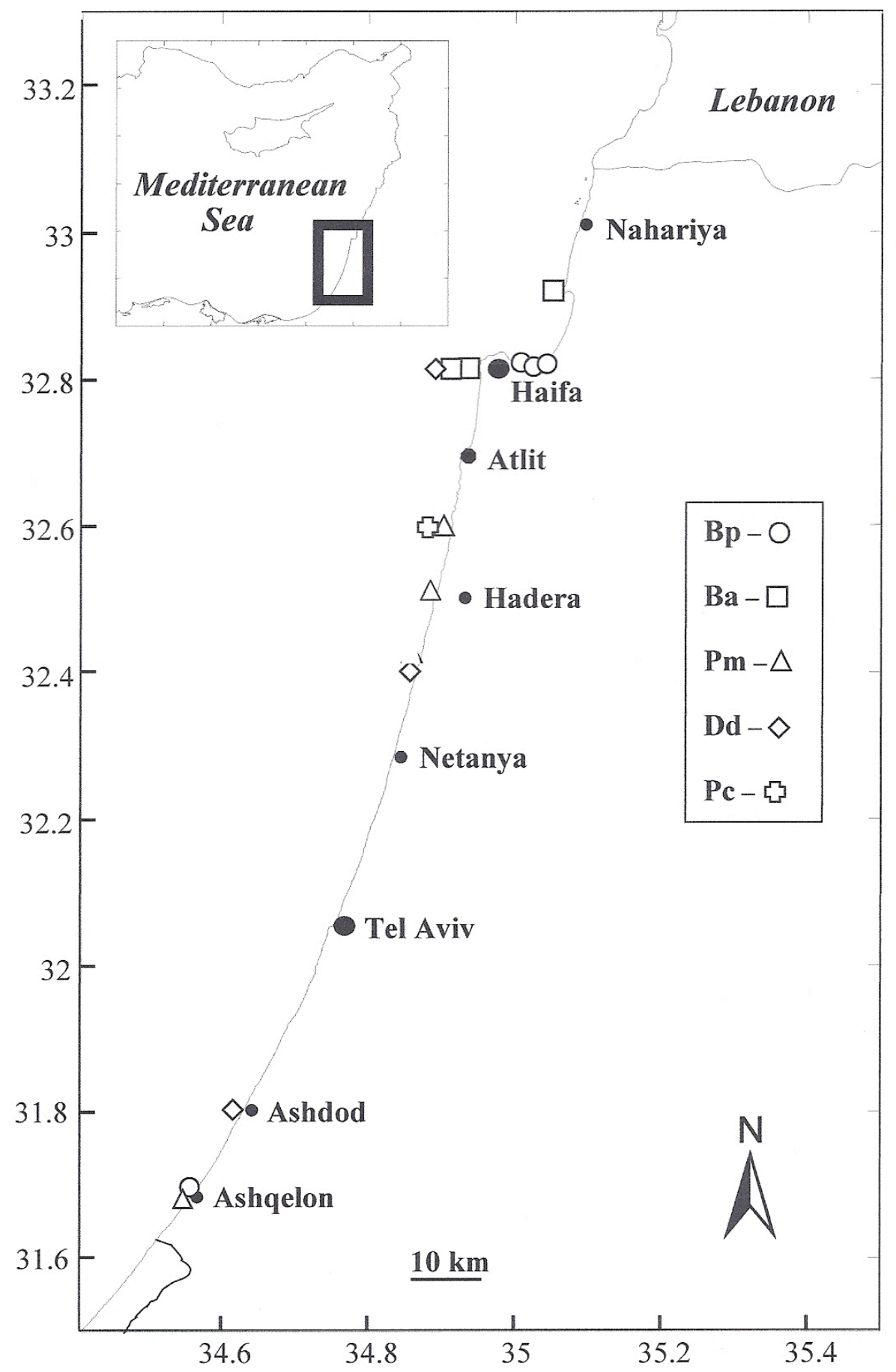

Fig. (6). Stranding sites of short-beaked common dolphin (Dd), false killer whale (Pc), minke whale (Ba), fin whale (Bp) and sperm whale (Pm) along the Israeli coastline, 1993-2009. 
Table 2. List of Cetacean (Other than Common Bottlenose Dolphin) Sightings off the Israeli Coast: 1993-2009

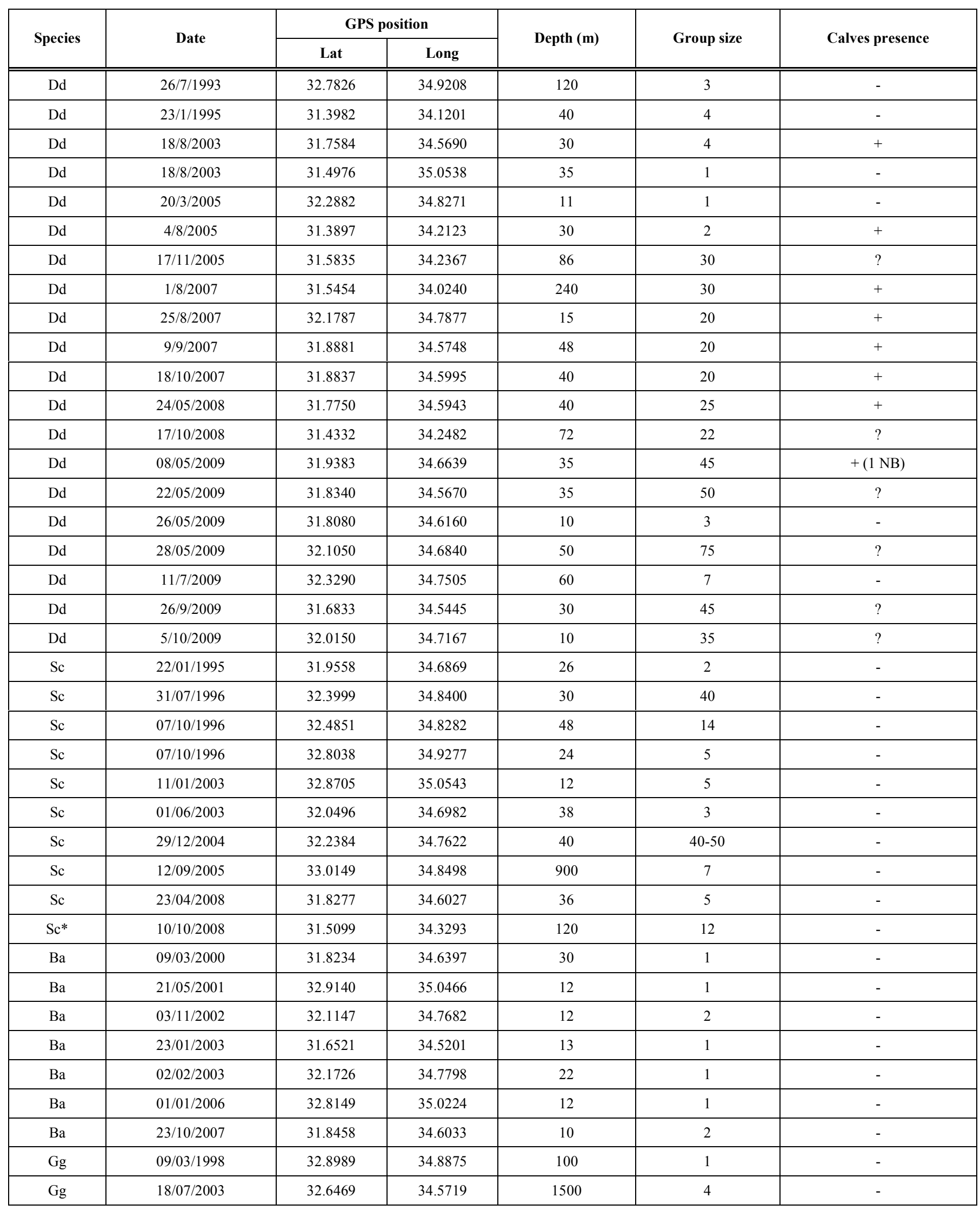


(Table 2) Contd.....

\begin{tabular}{|c|c|c|c|c|c|c|}
\hline \multirow{2}{*}{ Species } & \multirow{2}{*}{ Date } & \multicolumn{2}{|c|}{ GPS position } & \multirow{2}{*}{ Depth (m) } & \multirow{2}{*}{ Group size } & \multirow{2}{*}{ Calves presence } \\
\hline & & Lat & Long & & & \\
\hline $\mathrm{Gg}$ & $31 / 05 / 2004$ & 32.7500 & 34.5333 & 1300 & 2 & - \\
\hline $\mathrm{Gg}$ & $27 / 08 / 2004$ & 32.7063 & 34.9393 & - & 1 & - \\
\hline $\mathrm{Gg}$ & $27 / 06 / 2005$ & 32.9209 & 34.7547 & 1100 & 15 & + \\
\hline $\mathrm{Gg}$ & $15 / 04 / 2008$ & 31.9488 & 34.4059 & 350 & 8 & - \\
\hline $\mathrm{Pm}$ & $16 / 02 / 1999$ & 32.4123 & 34.8442 & 35 & 1 & - \\
\hline $\mathrm{Pm}$ & $28 / 01 / 2001$ & 31.9561 & 34.4169 & 300 & 2 & - \\
\hline $\mathrm{Pm}$ & $02 / 11 / 2002$ & 32.8432 & 35.0173 & 25 & 1 & - \\
\hline $\mathrm{Pm}$ & $05 / 07 / 2007$ & 31.8323 & 34.5828 & 36 & 1 & - \\
\hline $\mathrm{Bp}$ & $09 / 02 / 2007$ & 32.1723 & 34.7272 & 30 & 1 & - \\
\hline $\mathrm{Bp}$ & $26 / 07 / 2008$ & 32.8168 & 35.0050 & 14 & 1 & - \\
\hline $\mathrm{Zc}$ & $02 / 12 / 2003$ & 31.9695 & 34.5387 & 160 & 2 & - \\
\hline $\mathrm{Sb}$ & $22 / 3 / 2006$ & 32.8232 & 34.9905 & $5-10$ & $40+40$ & + \\
\hline
\end{tabular}

Abbreviations: Dd-Delphinus delphis, Sc-Stenella coeruleoalba, Gg-Grampus griseus, Ba-Balaenoptera acutorostrata, Pm-Physeter macrocephalus, Bp-Balaenoptera physalus, ZcZiphius cavirostris, Sb-Steno bredanensis. NB-newborn. *-Mixed group with short-beaked common dolphin.

Cuvier's Beaked Whale (Ziphius cavirostris, G. Cuvier 1823)

\section{Strandings}

Seven single male individuals have stranded during this time period. One of them was a live stranding of a juvenile in terminal condition. All strandings occurred between March and July, none of them further south than Tel Aviv.

\section{Sightings by Other Israeli Parties}

There is only one authenticated sighting by a trawler crew on December 2003 of a single individual off Ashdod, where water depth reaches $160 \mathrm{~m}$.

\section{Sightings by the $R / V$ 'Song of the Whale' Team}

One sighting and one acoustic detection were made off the Turkish Mediterranean coast on June, 2007, over water depths $>1000 \mathrm{~m}$.

\section{False Killer Whale (Pseudorca crassidens, Owen 1846) \\ Strandings}

One single stranding of a decomposed mature specimen occurred on Habonim beach on June of 2004. Given its craniometric characteristics, this was most probably a male of the North Atlantic population [17].

\section{Sightings by IMMRAC}

A pod of about 20 individuals was sighted and photographed by A.S. in the morning of March 2003, en route from Turkey to Israel, over a bottom depth of 1,800 m.

\section{Sightings by Other Israeli Parties}

Three group sightings of two, six and six individuals were reported westward of Nahariya, Haifa and Ashdod, respectively. All groups were sighted at water depths exceeding $900 \mathrm{~m}$.

\section{Sightings by the $R / V$ 'Song of the Whale' Team}

On June of 2007, a group of 3 individuals rode the boat's bow near the west coast of Cyprus, in water $940 \mathrm{~m}$ deep.

\section{Indo-Pacific Humpback Dolphin (Sousa chinensis, Osbeck 1765)}

\section{Sightings by IMMRAC}

In January 2000, IMMRAC staff was involved in an 11 day follow-up of a humpback dolphin of undetermined species and sex. This individual had been sighted consecutively in a north-to-south course along the coast from Atlit to Ashdod, taking refuge in bays and harbors from gale-force winds and $6 \mathrm{~m}$ high waves. It was most likely a member of the plumbea-type Indo-Pacific humpback dolphin [2].

\section{Cetacean Encounter Rate}

The R $\backslash \mathrm{V}$ 'Med Explorer' survey yielded 14 group sightings off Israel, 9 belonging to three species (common bottlenose, striped and Risso's dolphin) and 5 of unidentified delphinids, for an overall encounter rate of 1.06 groups $/ 100$ $\mathrm{km}$ of track-line.

The R\V 'Song of the Whale' team had encountered six group sightings of five different species (striped, rough- 
Table 3. List of Cetacean (other than Common Bottlenose Dolphin) Sightings in the LB Outside Israeli Waters: 2005-2009

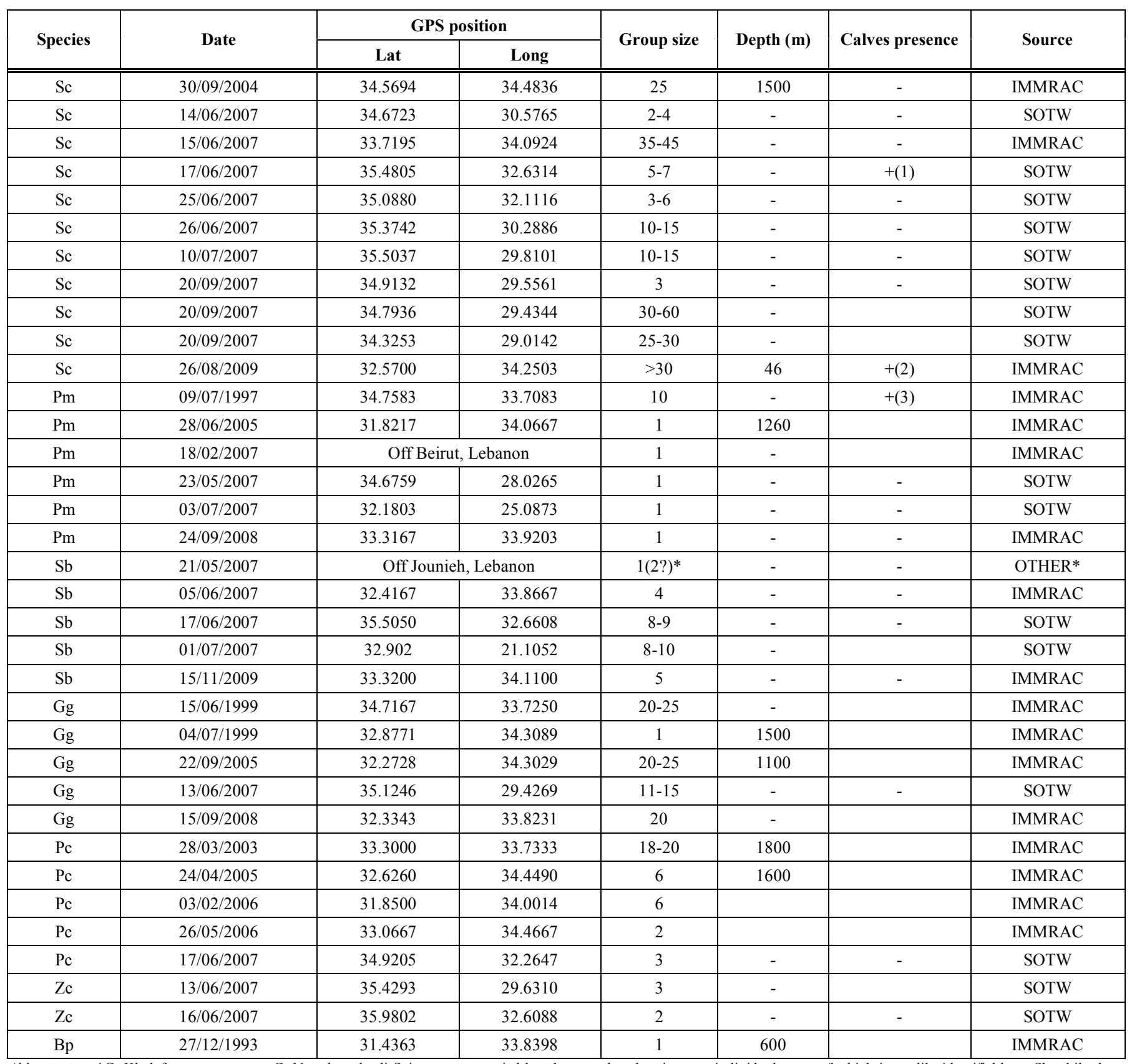

Abbreviation: *G. Khalaf, pers. comm. to G. Notarbartolo di Sciara, accompanied by photographs, showing two individuals, one of which is readily identifiable as Sb while the second may possibly be common bottlenose dolphin. Sc-Stenella coeruleoalba, Pm-Physeter macrocephalus, Sb-Steno bredanensis, Gg-Grampus griseus, Pc-Psudorca crassidens, Zc-Ziphius cavirostris, Bp-Balaenoptera physalus.

toothed and Risso's dolphin, sperm and Cuvier's beaked whale) and eight groups of unidentified delphinid species, 'on effort' across the LB. This translates to 0.46 groups/ 100 $\mathrm{km}$, not significantly different from the mean rate calculated for their entire Mediterranean survey.

\section{DISCUSSION}

\section{Regional Distribution}

\section{Israeli Continental Shelf (Fig. 7)}

The apparent concentration of sightings of pelagic species in the shallow $(<50 \mathrm{~m}) 10 \mathrm{~km}$ coastal strip is not indicative of true niche preference, but rather of where the majority of reporting agents are available for observation. Even rare sojourns of individuals of a deep-water species into these shallow waters are likely to accumulate over time, given the large amount of vessel and shore-based observer hours in the period covered by this report. In this regard, it is worth mentioning that all 14 sightings made during the 'Mediterranean-Explorer' line transect survey (including those of bottlenose dolphin) were beyond the 500 depth contour.

On the other hand, such observations may not necessarily be very rare. Considering the fact that many sightings of 


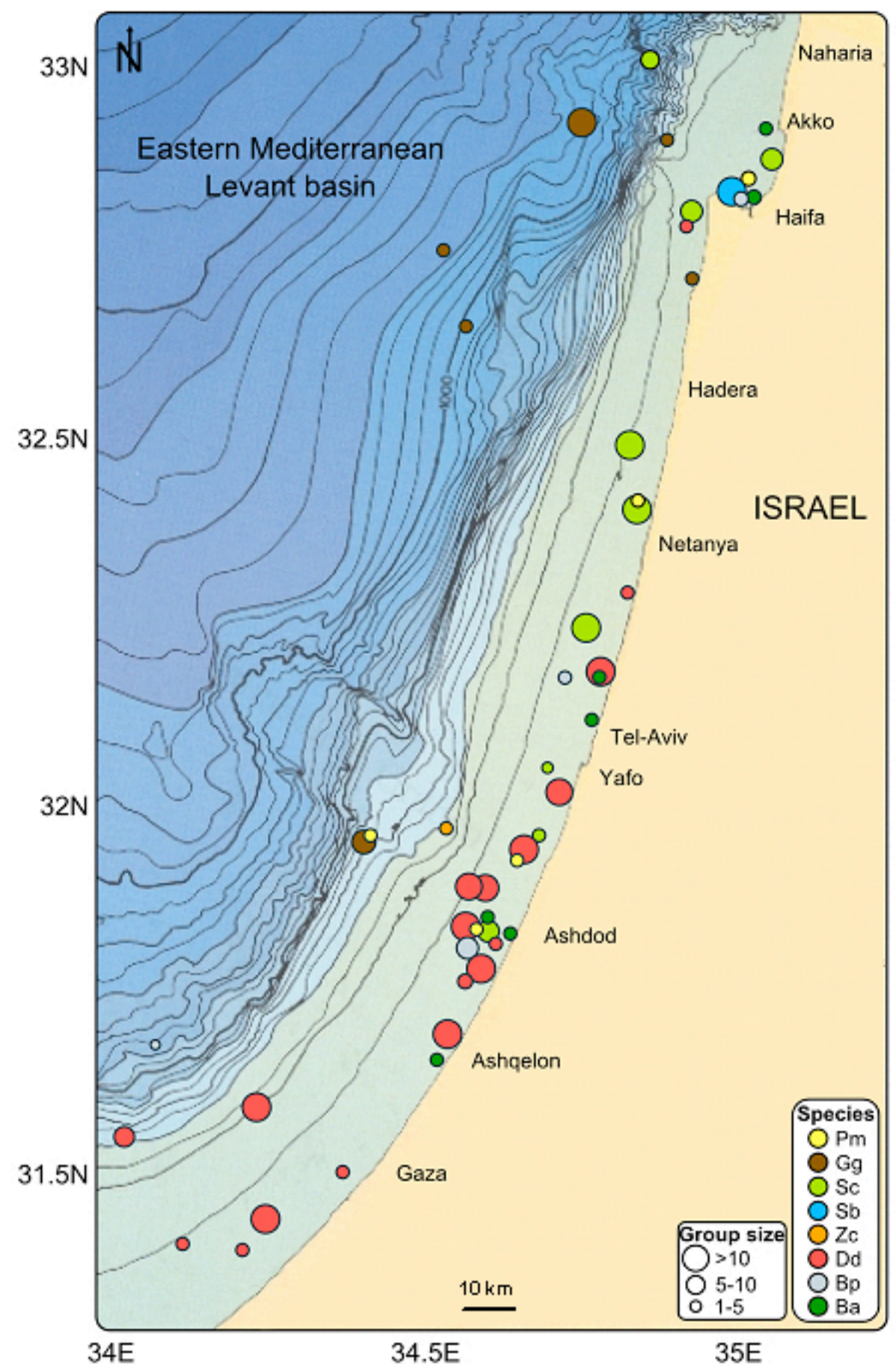

Fig. (7). Sighting sites of identified cetacean groups within Israeli coastal waters (out to $50 \mathrm{~km}$ ), 1993-2009. Isobaths are 50m apart. Bathymetric map origin is: Hall, J.K. 1994. Bathymetric chart of the Eastern Mediterranean Sea, in: V.A. Krasheninnikov, J.K. Hall, (Eds). Geologic structure of the northeastern Mediterranean (cruise 5 of the Akademic Nikolaj Strakhov), Geological Survey of Israel, Marine Geology, Mapping \& Tectonics Division, Jerusalem. Pm-Physeter macrocephalus, Gg-Grampus griseus, Sc-Stenella coeruleoalba, Sb-Steno bredanensis, Zc-Ziphius cavirostris, Dd-Delphinus delphis, Bp-Balaenoptera physalus, Ba-Balaenoptera acutorostrata,

whales and dolphins were not included in the current compilation, for lack of positive species identification, it would probably be safe to say that in this portion of the LB several of the open/deep water resident species routinely venture into very shallow waters. Notable exceptions may be false killer whale, with no sightings in local shallow waters and Risso's dolphin, with all but one of its seven sightings being over deeper waters.
In contrast to the in/out-shore distribution, the alongshore north-south distribution shown on the map may be more readily relied upon to picture the true state. Thus, for the two most frequently sighted species, the rather uniform distribution of the striped dolphin contrasts markedly with that of the short-beaked common dolphin, of which a medium to large group has never been reported north of Netanya, in the center of the coastline. 


\section{Levantine Basin (Fig. 8)}

Opportunistic second-party sightings in the easternmost portion of the LB are also spatially biased, since a major reporting source are private yachts that sail back and forth on fixed courses from Israeli to Cypriot and Turkish marinas. Sightings in the portions covered by transects of the $\mathrm{R} \backslash \mathrm{V}$ 'Song of the whale' should better reflect the true density distribution. A major drawback in this regard was the inability of the crew to survey the relatively shallow Egyptian waters (Figs. 3 and 8). Even so, it seems that waters off the Basin's northern shores, with greater shelf gradients and deeper seafloors are preferred habitats to the more abundant species such as the striped dolphin. Very few encounters (apart from common bottlenose dolphin) occurred at water depths $<200 \mathrm{~m}$

\section{Lessepsian Migration}

Since the opening of the Suez Canal in November of 1869, many invertebrate species, as well as fish, initially restricted to one of the two seas, made their way through the canal into the other one, the vast majority in the 'Red-toMed' direction [18-20]. Yet, there was no concrete, documented evidence that any marine mammal species had followed suit. Potentially, bidirectional passage through the Suez Canal is available to all resident and visitor cetacean species in the Gulf of Suez and the LB. Practically, it is the small coastal species that are most likely to pass through the $190 \mathrm{~km}$ long and up to $22 \mathrm{~m}$ deep corridor, and then, only in rare isolated instances. We will now address the possibility of the LB hosting Red Sea Lessepsian migrants.

\section{Indo-Pacific Humpback Dolphin}

The likelihood of the migration of this species into the LB has been mentioned in the past by Marchessaux [21].
Beadon [22] claimed it to be the fourth most frequently encountered species in the Gulf of Suez, including Port Said and Port Suez. The sighting by IMMRAC [2] this far north into the Mediterranean ( $\sim 450 \mathrm{~km}$ from the opening of the canal when hugging the shoreline) substantiates Marchessaux's conclusion. The occurrence of a single individual would fit the social structure of this species [23] although juveniles were reported to mainly occur as members of a group [22,23]. It may be surprising that this seems to be an isolated case. While a stranding of this species on the Israeli coast could hardly have passed unnoticed, sightings at sea could have mistakenly been attributed to Tursiops truncatus. Also the lack of active marine mammal centers and stranding networks in many of the states bordering the LB makes the possibility of other, unreported, migrants viable.

\section{Other Species}

Other cetacean species alien to the Mediterranean may stray into it via this route. Indo-Pacific bottlenose dolphin (Tursiops aduncus, Ehrenberg 1833) is prevalent in the Gulf of Suez $[22,24]$ and is a prime candidate for such migration. Unidentified bottlenose dolphins were sighted by A.S. inside the canal on three occasions during the Med-Red Rallies of 2005 and 2006. Two suspected Tursiops sp. carcasses with slightly spotted ventrums were stranded on the Israeli coast and tissue samples were sent for genetic typing (Peter Hale, University of Queensland, Brisbane, Australia). However, they turned out to be T. truncatus. Other potential migrants are pantropical spotted dolphin (Stenella attenuata, Gray 1846) and spinner dolphin (Stenella longirostris, Gray 1828), both known to inhabit the southern Gulf of Suez $[22,24,25]$. So far we have no evidence for any of them ever penetrating the LB. Lastly, the Indo-Pacific common dolphin (Delphinus capensis tropicalis, Gray 1828) has been docu-

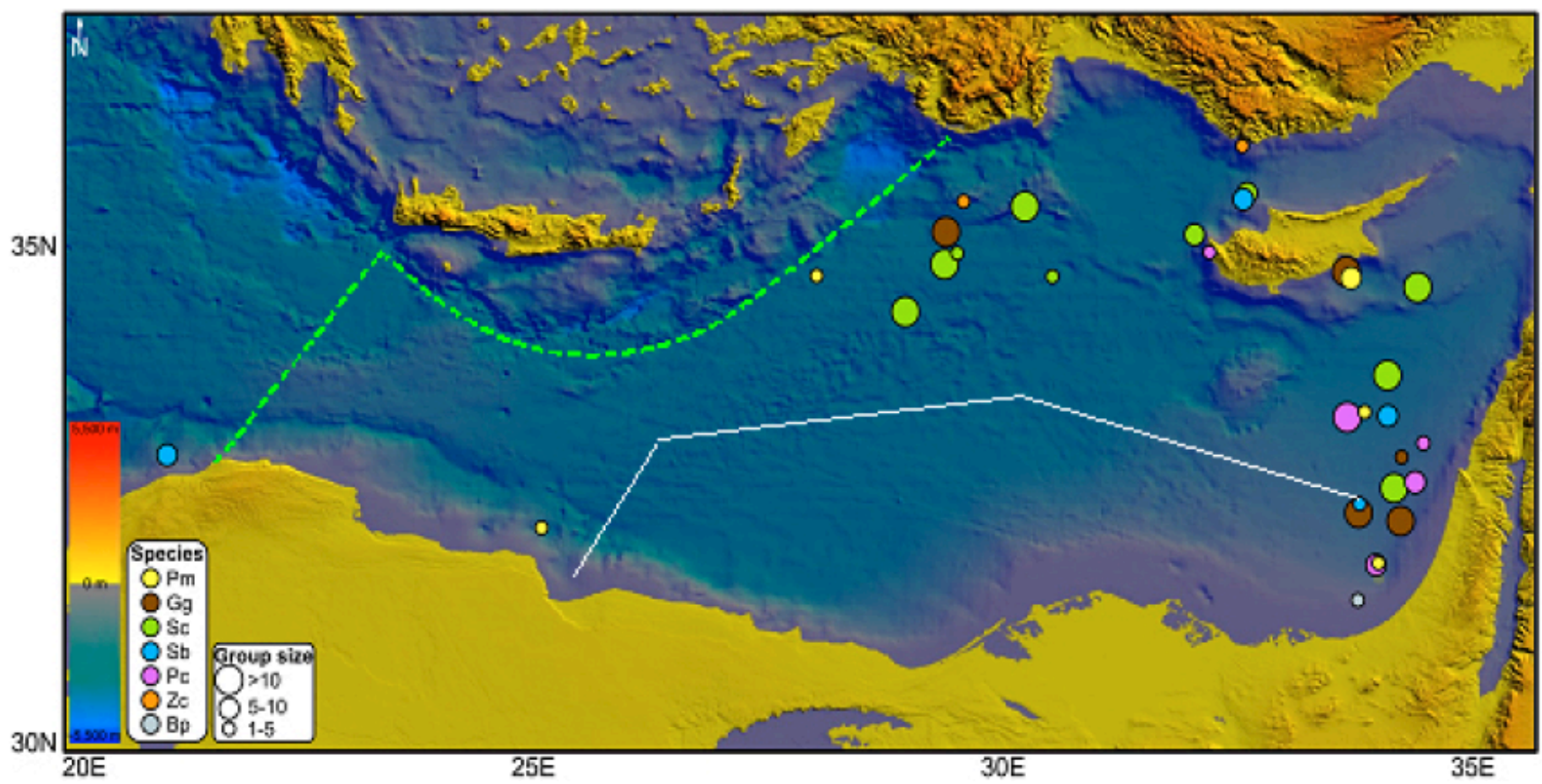

Fig. (8). Sighting sites of identified cetacean groups within the Levantine Basine, 1993-2009. Green dashed line is the western bound of the Levantine Basin, as defined in this report. Area south of white line was not surveyed by the R/V Song of the Whale. 
mented all along the Red Sea [26-28]. Flower [29] describes an encounter with two individuals of Delphinus sp. bowriding a steamer at the El Ballah bypass in the Suez Canal. All common dolphin records we have collected, as well as curated specimens in Israeli museums which we have examined, belong to the short-beaked species (Delphinus delphis).

A more complicated issue, the settlement of which would require genetic proof, concerns species that naturally reside in both seas and addresses the possibility that representatives of such species in the Mediterranean, and especially in its southeasterly corner, originate from Red Sea populations. Other than common bottlenose dolphin, false killer whale would be one point in question. It is quite common in the Gulf of Aqaba/Eilat [22], up to its northernmost tip ${ }^{2}$, and also enters the Gulf of Suez [22]. The movement range of individuals of this species, however, may not be extensive. A recent satellite-tagging study in Hawaii [30] showed an individual from the offshore population to have moved only $95 \mathrm{~km}$ from the point of tag deployment during 15 days. The investigators also tagged eleven animals from the insular population, with tag attachment durations ranging from 2-76 days. Despite traveling cumulative distances of some 3,300 $\mathrm{km}$ per individual, their average maximum distance away from the tagging site was only $202 \mathrm{~km}$ (greatest distance was $420 \mathrm{~km}$ ) [29]. Shoreward seasonal migrations that have been described around the islands of Japan were thought to be associated with movement of prey or flooding by warm ocean currents [31], conditions not relevant to Lessepsian migration. The apparent 'hotspot' of rough-toothed dolphin in the LB is also suggestive in this respect. The species reportedly occurs in the Red Sea [32], but so far has not been recorded in its northern gulfs.

\section{Regional Status for Species}

For the discussion below, we will assign each species recorded in the LB a status of regular, visitor or vagrant. Regular will be defined as a species known to reproduce in the area and/or predictably encountered year-round on an annual basis. Sightings/strandings of newborns or strandings of near-term mothers would support this status. Visitor and vagrant will receive the IUCN definitions [33], i.e. a species that does not reproduce within a region but regularly occurs within its boundaries and a species that is currently found only occasionally within the boundaries of a region, respectively. In order to quantify the predictability of occurrence, given that a reasonable degree of effort is regionally invested in surveying and/or documenting sightings and strandings, we will use several events in a decade and very few events in a century to describe visitor and vagrant, respectively.

Since the Israeli coastline and continental shelf do not contain known focal attractors for any cetacean species, we believe that we can project our findings to the LB as a whole, when assigning status. Israel's position in the transition between the Nilotic and Levantine sub-regions, may however allow some regional fine-structuring. Also, since effort still lags considerably behind that in the western

\footnotetext{
${ }^{2}$ Goffman, O., Roditi, M., Barnea, O. et al. 1996. Observations of cetaceans in the Gulfs of Eilat and Suez. Abstract. Proceedings of the $33^{\text {rd }}$ annual conference of the Zoological Society of Israel, Tel Aviv, 12-15/12/1996
}

parts, the projected frequencies are most probably underestimated.

\section{Common Bottlenose Dolphin}

A regular Mediterranean inhabitant, with wide-spread, albeit fragmented, coastal distribution [1]. Based on Israeli samples, the sub-population in the LB was found to be genetically differentiated from more western Mediterranean populations [34,35]. Recent cetacean listings from neighboring LB countries have common bottlenose dolphin ranking high on the list (e.g. [36-38]). Projecting evidence from Israel concerning year-round presence and strandings of newborns and pregnant females to the entire region, would undoubtedly earn it the status of a regular coastal species in the LB.

\section{Striped Dolphin}

An oceanic delphinid that is the most abundant cetacean in the Mediterranean, where it demonstrates a declining west to east abundance gradient. This probably reflects the Sea's parallel gradient in primary productivity and carrying capacity for top predators [1]. Its Mediterranean population is genetically differentiated from that of the eastern North Atlantic and based on samples from the Ligurian, Tyrrhenian and Ionian seas, also shows inter-basin genetic structure [39]. Marchessaux [21] stated that the striped dolphin does not occur east of $30^{\circ}$ longitude. This statement probably stemmed partly from lack of effort and partly from failure to distinguish carcasses of this species from those of common dolphin. Holdings of several striped dolphin skulls in the collection of Tel Aviv University Museum were erroneously listed as common dolphin. More recently, this species has been reported from Turkish $[36,40,41]$ and Cypriot ${ }^{3}$ waters. The mean group size of LB sightings is in good accordance with other parts of the Mediterranean (Table 4), apart from the lack of sightings of groups $>50$ individuals in the LB.

A collaborative account on several abundance estimation surveys by different research groups in the Pelagos sanctuary, Corso-Ligurian basin [48] found offshore groups (water depth $>2000 \mathrm{~m}$ ) to be significantly larger sized than onshore groups: mean=21.5; median=16 $(\mathrm{N}=124)$ and mean $=13.1$; median $=6(\mathrm{~N}=37)$, respectively. No such difference was found in the LB, possibly because of the small number of sighting.

Strandings of striped dolphins off Israel never included newborns or very young calves. A possible explanation is that dead calves of this pelagic species are less likely to be washed ashore. Also, the rarity of calf sightings in this report may be caused by young calves usually being members of large groups, making it hard for unskilled observers to tell them apart. All evidence considered, the striped dolphin can be counted as a regular year-round resident of the LB.

\section{Short-Beaked Common Dolphin}

A once widespread and very common Mediterranean inhabitant, the last half century has witnessed a profound reduction of the former range and size of its Mediterranean

\footnotetext{
${ }^{3}$ Hadjichristoforou, M. 2004. ACCOBAMS first national implementation report of Cyprus. Document MOP 2/Inf 35: ACCOBAMS Second Meeting of the Parties, Palma de Mallorca, 09-12/11/2004. Available from: http://www.accobams.org/index. php?option $=$ com_docman\&task $=$ cat_view\&gid $=38 \&$ Itemid $=50$
} 
Table 4. Group Sizes of Striped Dolphin In Various Mediterranean Basins

\begin{tabular}{|c|c|c|c|c|}
\hline Basin & N & Mean $( \pm$ SD) & Range & Fortuna et al., 2007 [42] \\
\hline \hline Southern Tyrrhenian & 40 & $15.1 \pm 15.7$ & $1-60$ & Forcada \& Hammond, 1998 [43] \\
\hline Ligurian & 28 & $14.2 \pm 15.3$ & & Laran \& Drouot-Dulau, 2007 [44] \\
\hline Ligurian & 216 & $17 \pm 8$ & $1-140$ & Lauriano et al., 2010 [45] \\
\hline Ligurian & 37 & $7.51 \pm 7.4$ & $1-35$ & Forcada \& Hammond, 1998 [43] \\
\hline Provençal & 44 & $13 \pm 14.6$ & & Gaspari, 2004 [46] \\
\hline Corso-Ligurio-Provençal & 1492 & $17 \pm 19.58$ & $1-200$ & Gómez de Segura et al., 2006 [47] \\
\hline Western Balearic & 162 & 15.7 & $1-100$ & Present study \\
\hline Levantine & 22 & $16.9 \pm 15.8$ & $2-45$ & \\
\hline
\end{tabular}

population, the Sea now being the last stronghold of relative abundance [1]. Curiously, the genetic profile of the Alborán subpopulation was found to more closely resemble that of the eastern North Atlantic than that of the Ionian subpopulation [49]. The authors suggest that this finding could be explained by isolation arising from differences in habitat utilization with the former subpopulation mainly utilizing beyond-shelf oceanic waters while groups of the latter are more often encountered in the shallower neritic zone. The species has an established record in the LB $[21,29,50]$ and it too is included in all of the above-mentioned regional current compilations. The record from Israel is rather poor on strandings. Yet, the frequent sightings in the last five years of large groups with young calves are encouraging, given the dire state of the Mediterranean sub-population of this species [51], recently awarded a 'threatened' status under the IUCN Red List [1]. According to the latter report, such large groups are still seen in the Alborán Sea and seasonally around Malta, but are rare in the Eastern Basin, including the Aegean Sea. Indeed, the relatively undisturbed southeastern corner of the latter may be drawing individuals from less suitable habitats in the Basin. Common dolphins in the Mediterranean and elsewhere mainly feed on small epipelagic shoaling fish of the Clupeidae and Engraulidae families $[52,53]$. Ironically, the regional human strife may have formed another incentive for occupation by common dolphins, since the Israeli imposition of a naval blockade on the Gaza Strip has substantially restricted local purse-seine fishing. If this is substantiated by future dedicated surveys, these waters should be given special attention in conservation management plans for the species. Based on our new findings, the short-beaked common dolphin too should be included in the regional regular category. The paucity of sightings in the Israeli northern coast and the notable zero encounter rate by the 'Song of the Whale' team, would suggest qualifying that assertion to the southern or southeastern reaches of the LB.

\section{Risso's Dolphin}

The Risso's dolphin is considered a regular inhabitant of the Mediterranean and scarcer in the eastern basin, probably due to paucity of regional surveys [1,54]. It is a pelagic teutophagous species and its main habitat in the northwest Mediterranean lies beyond the shelf and above the upper part of the continental slope, with a mean depth of $638 \mathrm{~m}$ [55]. It is genetically differentiated from the eastern north Atlantic population, which based on samples from the Ligurian and Ionian Seas, has some internal structure [56]. Its listing varies between the LB countries. Two single strandings were reported along the Turkish Mediterranean coast, one off Fethiye in May of 1995 and one off Alanya in August, 1998 [57]. It has also been reported to occasionally get caught in swordfish driftnet operations along that coast [41]. Off Cyprus it is considered rare (M. Hadjichristoforou, footnote 4). A single adult animal was successfully refloated after stranding near Famagusta on May, 2008 (B.A. Cicek, personal communication backed by photos). Between 20022008, no beachings of Riso's dolphin were listed in Syria [36]. Earlier reports [21,29] do not list it as a resident in Egyptian waters.

Our report contains six stranding events and 11 sightings, scattered over wide geographical areas (Figs. 6, 7) and demonstrating year-round presence. Mean group size of 10 in the LB is on the lower side of the range of 12-37 for mean group sizes of this species reported in eight dedicated survey studies in western Mediterranean basins [54], non of which presents data detailed enough for a statistical comparison. Also, in all of the studies mentioned in [54], groups larger than 25 (the largest sighted in the LB) were encountered. To take an example from a 10 year study in the Ligurian Sea with 110 encounters [46], 14 groups $>25$ animals (range 3070) were encountered. The fraction of single animal sightings in that study was only 0.0363 , significantly smaller than a fraction of 0.273 in the LB encounters, (Fisher's Exact Test; $\mathrm{p}<0.0138$ ). Even though we have no evidence for reproduction in the area, we tend to include this species among the regulars of the LB. As in the western Mediterranean it has been reported to frequent waters above submarine canyons and seamounts [55], the northeastern corner of the LB and Eratosthenes seamount are potential regional hotspots and recommended targets for future dedicated surveys.

\section{Rough-Toothed Dolphin}

Another seemingly rare inhabitant in the Mediterranean, the rough-toothed dolphin's status in the Mediterranean has recently been upgraded from 'visitor' to a 'regular', mainly based on its encounter rate in the LB [1]. We are aware of 
only one historical record of this species in the LB prior to the period covered by this report. It is of a specimen collected near Haifa, Israel in 1949, the skull of which is kept at the British Museum [21]. During the last decade, apart from the eight Israeli strandings, only five other reports were found for the entire Mediterranean basin, three of them in the LB: Centro Studi Cetacei reported on a group of six animals that stranded alive on the beach of Donnalucata, southern Sicily, on April 5 ${ }^{\text {th }}, 2002$ [1], Fundaciõn Aspro Natura reported on a single mummified individual, found on June $6^{\text {th }} 2004$ near Ibiza in the Balearic Islands [58], two females, one pregnant, were bycaught in a gill-net on March $3^{\text {rd }} 2009$ in Lebanon ${ }^{4}$ and a group of about 20 individuals stranded alive and then successfully re-floated on March $10^{\text {th }}$ in Limassol Bay, Cyprus ${ }^{5}$. Adding to the six sightings that we report here two older sightings in the Ionian Sea, one of 160 animals with calves on September $4^{\text {th }}, 1985$ [59] and another of a group of eight animals including a calf on September $24^{\text {th }}, 2003$ by the crew of the R\V 'Song Of The Whale' ${ }^{\prime 6}$ its status in the Mediterranean should indeed be raised to regular, mainly on account of its seemingly preferred residence in the LB.

The apparent seasonality (February-June) of all but one of the LB records may hint at some annual migratory behavior. One possibility is into and out of the Sea via Gibraltar Strait or the Suez Canal, but the species has neither been recorded in the Strait nor in the Gulf of Suez. More likely, the movement may be that of a resident deep water population which migrates in the spring to near-coastal waters where they are more likely to be spotted. This migration could be driven by movement and schooling patterns of preferred prey. Worldwide, the species is mostly encountered over deep waters, but sightings in shallow waters are not uncommon [60]. Calving in the shallows could be another spring shoreward incentive, even though a longitudinal study of a resident population off La Gomera, the Canaries, did not reveal a distinct calving season $(\mathrm{F}$. Ritter, personal communication). With this species too, foraging near the shore takes its toll. Four of the five reported fresh mortalities (Israel \& Lebanon) were known victims of gill-net entanglement.

\section{Cuvier's Beaked Whale}

This species is poorly known, in the Mediterranean as elsewhere. Its involvement in atypical mass strandings following the employment of military mid-frequency active sonar and seismic underwater air-gun arrays, spurred worldwide effort to better understand its biology [61]. The Cuvier's beaked whale maintains a resident sub-population in the Mediterranean [1] that according to preliminary genetic analysis seems to be distinct [62]. The first report of this species in the LB was of a specimen washed to shore near Tel Aviv [63]. Since then and before the period covered by this report, one other single stranding event was reported in

\footnotetext{
${ }^{4}$ Gonzalvo J. 2009. Training activities in Lebanon and Syria. FINS, the Newsletter of ACCOBAMS 4(2):16. (Available from: http://www. accobams.org/2006.php/newsletter/all).

${ }^{5}$ Andreas Demetropoulos, personal communication, with photographs.

${ }^{6}$ Lacey C, Lewis T, Moscrop A. Sightings made during surveys of Mediterranean Sea in 2003 and 2004 including an unusual encounter with rough-toothed dolphins (Steno bredanensis) in the Ionian Sea. Abstract \# SA-13. In: $19^{\text {th }}$ Ann. Conference of ECS, La Rochelle, April 2005.
}

Karataş, the Turkish Mediterranean coast, on September 1982 [64]. In the said period, in addition to our listing, four more strandings were reported in Turkey: three of single animals, in Serik, on July 1994 [36], in Ören, on March 1995 [36] and in Fethiye, on January 2002 [53] and one of two live individuals that later died, in Bozyazi, on April 2001 [61]. In addition, three single strandings were reported in Syria, a male in El Basit on March 2005, one of unspecified sex in Borj Islam in April-May 2005 and a very young female in El Rmieleh on March 2008 [37].

A review of Mediterranean strandings of this species [65], lists 271 cases between 1961 and 2003. The Mediterranean Database of Cetacean Strandings - MEDACES [58] lists another 29 single-stranding cases from Spain, France, Italy and Greece during 2004-2008. Adding holdings of five animals from the Tel Aviv University Museum collection from years 1960-1980 (mandibles of one more specimen were collected in 1968 on the seaward sand-bar of Sabkhat el Bardawil, northern coast of Sinai Peninsula, Egypt) to the seven described in this report, the Israeli coastline was the final resting place of $4 \%$ of the reported Mediterranean strandings. Comparing the strandings in Israel in the period 2000-2007 to those of a well-monitored Mediterranean coastline such as the Spanish one [58], the mean stranding frequency in Israel is twice as high: 0.35 and 0.17 strandings per $100 \mathrm{~km}$ coastline per year, respectively. Yet, more than half of the Spanish strandings (16 out of 30) were along the coast of Almeria province (ibid.), which is a known 'hotspot' of the species [66]. In that region, strandings reach a frequency of 0.8 per $100 \mathrm{~km}$ per year. Similar considerations prompted Holcer et al., [67] to consider the southern Adriatic as a potentially important Mediterranean habitat for the species. We, however, believe that too little is known about it to warrant such conclusions and that bias-prone stranding records should be matched by regional sighting records to be gained through dedicated regional survey efforts.

All considered, we agree with Marchessaux's [21] statement: "This pelagic and teutophagous species probably finds good feeding grounds in the eastern Mediterranean...where it is likely to occur as commonly as in the western basin." and ascribe a regular status to Cuvier's beaked whale in the LB. Along the Israeli coast, strandings are restricted to the northern steeper-sloped part, suggesting that the southern coastline and probably the entire southeastern corner of the Basin do not comprise a portion of its biological niche. This conclusion is supported by recent, unpublished, model-predicted distribution maps of Cuvier's beaked whale in the Mediterranean. The maps confine the potentially suitable habitat for the species in the LB to its north-east corner (A. Caňadas, personal communication).

\section{Sperm Whale}

A regular resident in the Mediterranean, with wide distribution over deep waters, but considered rare in the LB [1]. Visual detection probability of long-diving mammals like the sperm whale is rather low [68] and dedicated surveys for such species are usually supplemented by acoustic detection means (e.g. [69]). Since the latter are only available on research or on military vessels, it would be expected that an opportunistic sighting record would underestimate sperm whale preponderance. The Mediterranean population is 
genetically differentiated from the Atlantic populations and, based on a sample that did not contain LB representatives, has zero mitochondrial DNA diversity [70]. Aharoni [63] documented the only record of sperm whale in the LB prior to the period covered here. He reports that an individual (sex unspecified) a little over $7 \mathrm{~m}$ long beached on the shore of Herzliya on 1935. Its skeleton was later buried in Jerusalem (now lost). Since then, the record in the LB is sparse. The species was detected during the two dedicated regional surveys with acoustic detecting capability, IMMRAC's and that of the R\V 'Song of the Whale'. Their records as well as those reported by second parties were of single individuals or of pairs, the only exception being a social group sighted near Cyprus on July of 1997. Off Cyprus, the species is considered rare (M. Hadjichristoforou, footnote 4), while the stranding list from Syria contains only one entry of a $10.5 \mathrm{~m}$ long individual on April 2005 [37]. Habitat preference modeling in the northwestern Mediterranean [55] found the preferred niche to be over the deeper part of steep continental slopes and adjacent offshore waters, at a mean depth of $1750 \mathrm{~m}$. Such habitat exists in the LB, mainly in its northern part and further dedicated acoustic surveys may establish the species' regular presence in the region. Until that time, we are more comfortable ascribing a visitor status to the sperm whale in the LB, noting its apparent year-round residency in the Helenic Trench [4].

\section{Fin Whale}

A regular inhabitant in the Mediterranean, as evident from a 2003 review [71], where 2450 published and original records in the basin from 1800 up to 2001 are listed. Of these, only 10 are from the LB, with only a single record of a newborn, sighted in Larnaka Bay, Cyprus on October 21,2001 . In addition, we are aware of two other published single stranding incidents in the LB, prior to the period covered by the present report. The first is of an $11.5 \mathrm{~m}$ long young calf found in Dakhla, north-eastern Sinai, in 1980 [72]. The second is of a specimen estimated to have measured $17 \mathrm{~m}$ that washed up on the shore of Megadim on February of 1981 in a decomposed state and was buried on site [73]. The former source also states that in the nineteen thirties and forties, three meter long lower jaws of fin whales would occasionally be brought up inside bottom trawl nets operating from Jaffa. Other than the cases in the present report (none of which appear in the above-mentioned 2003 review), another stranding of a freshly dead male calf in the province of Adana, Turkey, in May of 2003, was reported by the Turkish Marine Research Foundation [58]. The available record in the LB reveals a size/age distribution with a relative preponderance of weanlings and young calves in fin whale strandings. The mean length $( \pm$ SD) in the Basin's stranding records for which this information is available $(\mathrm{N}=11)$ is $11.9( \pm 2.78) \mathrm{m}$, with no record of an animal larger than $17 \mathrm{~m}$ or smaller than $7 \mathrm{~m}$. The same values for the Mediterranean as a whole $(\mathrm{N}=103)$, are: $14.1( \pm 5.38) \mathrm{m}$, with $25 \%$ of the records being larger than $17 \mathrm{~m}$ and $17 \%$ smaller than $7 \mathrm{~m}$ [71]. The medians of the two samples, 11.5 and 14.25 , respectively are significantly different (Independent-samples Median Test; $\mathrm{p}=0.038$ ).

The ultra-olygotrophic LB can hardly sustain the feeding requirements of large rorquals. Is the $L B$, then, a death trap for straying fin whale calves and juveniles or could it possibly be a preferred wintering ground for part of the Mediterranean population? The relative regional scarcity is evident from the very low stranding rate: 0.22 strandings/100 $\mathrm{km}$ coastline/year in Israel, as compared to a range of 1.79 7.64 strandings $/ 100 \mathrm{~km} /$ year for various coasts of Italy, Sicily and Sardinia [74]. The locations of the wintering/ reproductive abode(s) of the spring-summer feeding aggregations of fin whale in the Ligurian Sea are as yet unsettled. Notarbartolo di Sciara et al., [71] argue that if indeed the Mediterranean fin whale population is endemic, as suggested by genetic studies [75], the oceanic model of seasonal lengthy migrations may not pertain and that the Mediterranean probably supplies both feeding and reproductive needs. They further suggest that Mediterranean breeding grounds may not exist at all and that a widely, even if not homogenously, dispersed Mediterranean population aggregates in the north-western parts of the basin in spring-summer to feed. It is therefore quite possible that dedicated winter surveys throughout the ranges of the LB and the Ligurian Sea would yield similar densities. Traveling to the feeding grounds, even from the furthest corner, would then be covered in a short time. The young calf that "adopted" the Turkish freighter covered $300 \mathrm{~km}$ in $48 \mathrm{~h}$. Moving between the LB and the Ligurian Sea at that speed would take about 7-10 days.

The best available evidence to date would confer a visitor status to the fin whale in the LB.

\section{Common Minke Whale}

A widely distributed whale in the northern hemisphere, more often observed nearshore, which unlike the bigger rorquals has a diverse diet that in addition to swarming invertebrates also includes small schooling fish [76]. The species has been defined as a visitor to the Mediterranean [1]. The authors list 13 occurrences outside the LB during the period 1990-2006, however, for the period of 1993-2007 there are 35 additional listings of minke whale strandings on the Spanish Mediterranean coast reported by Centro de Recuperaciõn de Especies Marinas Amenazadas (CREMA) and four on the French Mediterranean coast reported by Groupe d'Etude des Cétacés de Méditerranée [58]. Adding our own records, we calculate a rate of around four occurrences per year for the Mediterranean. This frequency is an order of magnitude above the 'several occurrences in a decade' definition for visitor status. However, to-date, no evidence supports reproduction of the species in the Mediterranean. While the majority of the records are of juveniles and calves, the latter seem to be already on the verge of weaning and independence, possibly making them vulnerable to entanglement in fishing nets. Furthermore, Mitochondrial DNA control region testing found the haplotype of the male calf entangled off Acko to be identical to the most common haplotype observed among whales sampled in the North Atlantic [13] and entrance to the Mediterranean by a tagged Atlantic minke whale has been reported ${ }^{7}$. All considered, the visitor status seems appropriate for the common minke whale in the LB as well as in the entire Mediterranean.

\footnotetext{
${ }^{7}$ Teilmann J, Dietz R, Eskesen I. 2004. A journey of a minke whale - from Denmark to the Mediterranean. European Research on Cetaceans 18 (presented poster).
} 


\section{False Killer Whale}

Prior evidence for its occurrence in the LB is scant. A portion of a skull was found on a beach near Baltim in the Nile delta in Egypt [77] and a single individual stranded live in Izmir Bay, Turkey [36]. Encounters with this species in the LB yield a median group-size of $6(n=5)$, which is significantly smaller $(p<0.01$, Mann-Whitney $U$ test) than in the western Mediterranean $(20 ; n=7)$ [1]. The normal groupsize of 20-30 for the species [78], has been encountered only once in the LB. The pelagic nature and the occurrence over the shelf edge and beyond, onto deep waters does fit other accounts, e.g. [79]. The somewhat shallower occurrence west of Cyprus (Fig. 7) is also in accord with the species' habit of approaching the shallows around oceanic islands, where deep water is a short distance away $[22,80]$. Formerly considered very rare in the Mediterranean $[81,82]$, it too received a visitor status by Notarbartolo di-Sciara \& Birkun [1], who listed four records outside the LB between 1990 and 2006. During 1997-2007, CREMA reported five additional single strandings off Spain, and ARION reported one off Greece [58]. Since more than half of the reported occurrences in the last decade are in the LB, this species definitely deserves a visitor status in this region.

\section{Vagrant Species}

Indo-Pacific humpback dolphin's vagrancy in the Mediterranean is limited to the LB, since so far it has only been sighted in Egyptian and Israeli waters [2]. Investing more search effort in the south-eastern corner may yet elevate its status to visitor. Killer whale (Orcinus orca, Linnaeus 1758) and humpback whale (Megaptera novaeangliae, Borowski 1781) should be considered as vagrants in the Basin, with one record each in the region ([50] (but see below) and Saad, $2004^{8}$, respectively). Lately, a very unusual live stranding of what was most likely a Gervais' beaked whale (Mesoplodon europaeus, Gervais $1855)$ occurred in the Basin ${ }^{9}$. Since this was only the second reported case of this species in the Mediterranean [83], vagrancy and/or elusive residence for this and other species of Mesoplodon remains to be determined. Finally, an astounding case of extreme vagrancy presented itself in May of 2010, when a gray whale (Eschrichtius robustus) was sighted off the Israeli Mediterranean shore and twenty two days later, the same individual was sighted in Spanish Mediterranean waters [84].

Table 5 summarizes suggested status assignments as compared to those for the Mediterranean as a whole [1].

\section{On Misidentification}

Misidentification is a problem riddling just about all attempts at establishing a regional species composition possibly more so in the case of cetaceans - and the LB is no exception. When identification at sea is unbacked by photographs it might be questioned in the best of circumstances, but even respected zoologists may misidentify cetacean skeletal remains or even fresh stranded animals, for lack of

\footnotetext{
${ }^{8}$ Saad A. First record of a humpback whale stranding on the coast of Syria (Eastern Mediterranean). FINS, the Newsletter of ACCOBAMS 1(1):10

${ }^{9}$ Notarbartolo di Sciara G. 2009. Stranding of a rare beaked whale in Turkey. FINS, the Newsletter of ACCOBAMS 4(2):15.
}

Table 5. Status of Cetacean Species in the Mediterranean as Assigned in [1] and in the LB, as Suggested by the Current Report

\begin{tabular}{|c|c|c|}
\hline Species & Mediterranean & LB \\
\hline \hline Tursiops truncatus & Regular & Regular \\
\hline Stenella coeruleoalba & Regular & Regular \\
\hline Delphinus delphis & Regular & Regular \\
\hline Grampus griseus & Regular & Regular \\
\hline Ziphius cavirostris & Regular & Regular \\
\hline Balaenoptera physalus & Regular & Visitor \\
\hline Physeter macrocephalus & Regular & Visitor \\
\hline Globicephala melas & Regular & Absent \\
\hline Steno bredanensis & Regular & Regular \\
\hline Balaenoptera acutorostrata & Visitor & Visitor \\
\hline Pseudorca crassidens & Visitor & Visitor \\
\hline Megaptera novaeangliae & Visitor & Vagrant \\
\hline Orcinus orca & Visitor & Vagrant \\
\hline Sousa chinensis & Alien vagrant & Vagrant \\
\hline
\end{tabular}

experience and/or access to a comprehensive comparative collection. Consider the Israeli example: eminent zoologists of the German school came to the country in the early $20^{\text {th }}$ Century without a solid background in cetology and had no opportunity to develop such a background after their arrival. As a result, striped dolphin skulls were cataloged as common dolphin in the Tel Aviv Museum and a 1990 authoritative Encyclopedia of Plants and Animals of the Land of Israel (in Hebrew) shows a picture of a striped dolphin above a caption of a common dolphin, the former not being listed among local species. Some claims seem credible according to the description or because they fit with more updated information. Others, however, are highly questionable, like the often quoted isolated mentioning of the killer whale by Bodenheimer [42], since no details are given as to whether it was sighted live, seen freshly stranded, or identified from skeletal remains. In the same source, Bodenheimer raises a possibility based on etymological grounds that beluga whales (Monodon monocerus) were the source of leather for the portable tabernacle tent of Biblical times, which further raises doubts as to his cetological acumen.

Identifying cetacean species from skeletal items entails a particular margin of error, as evident from several "first in a region" claims made without consulting with experts. For a case in question, a skull found a few $\mathrm{km}$ South of Lattakia, Syria, was identified as belonging to false killer whale [85], while the supporting photographs show it to be Risso's dolphin (Fig. 9).

\section{CONCLUSIONS}

The major point arising from this review is that the LB, despite its relatively impoverished biomass, is worthy of much more investigative effort than hitherto invested there, and that it may hold many rewards and surprises for whoever would be willing and capable of so doing. Except the longfinned pilot whale which apparently does not attempt to 


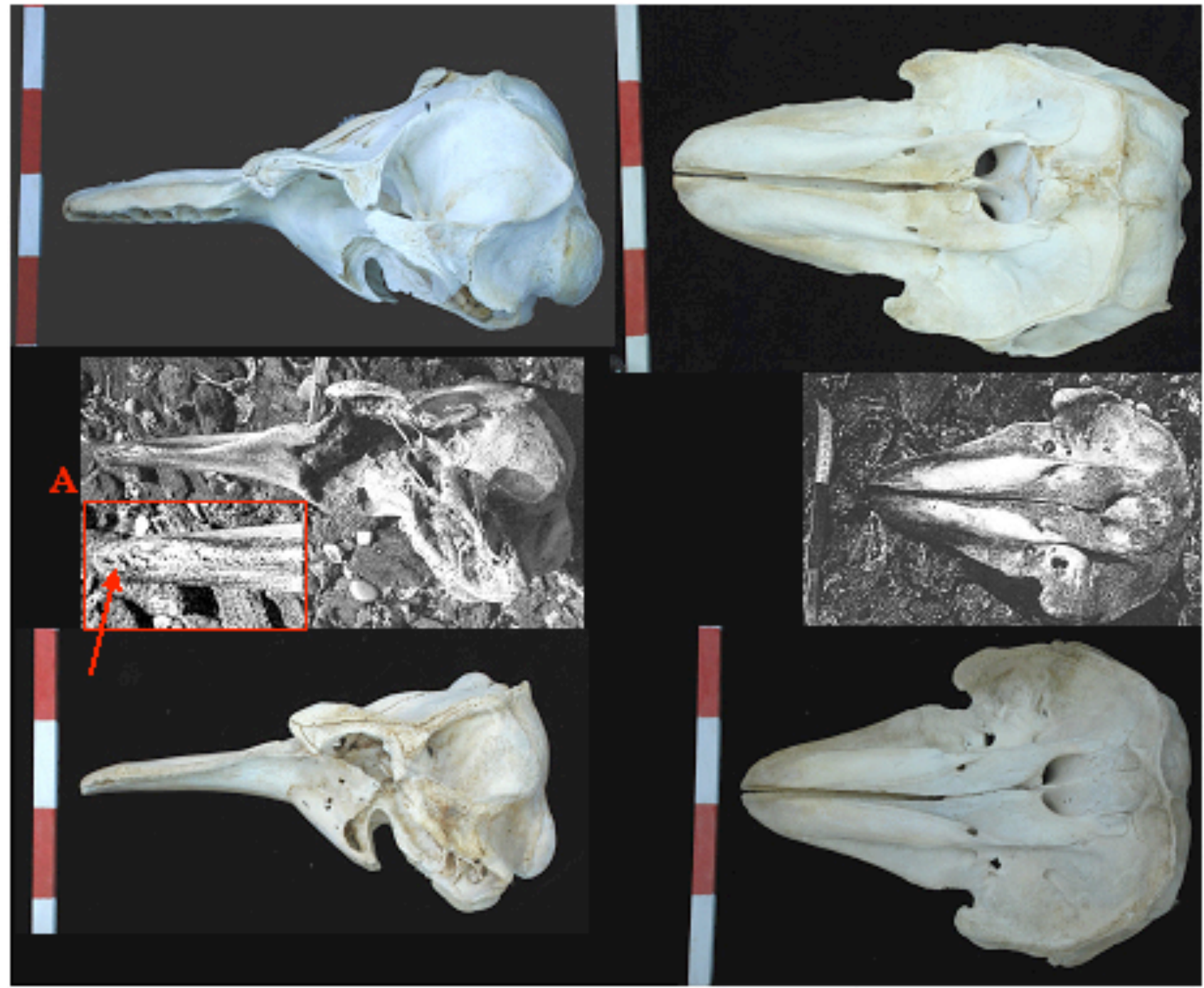

Fig. (9). Dorsal and lateral views of, top to bottom: Adult false killer whale skull (IMMRAC collection), 'Syrian skull' in Kasparek 1997 [71] and adult Risso's dolphin skull (IMMRAC collection). Scales have $10 \mathrm{~cm}$ divisions. All pictures except 'A' are matched to scale, such that relative sizes are maintained and showing the Syrian skull to be that of a calf. Picture A was expanded to stress the presence of teeth alveoli in the tip of the jaw only (inset and arrow), the most notable among many features that would assign the skull to the latter species.

cross the shallows of the Sicily Channel, all other resident Mediterranean cetacean species are encountered within its bounds, either regularly or seasonally. One may even hazard a guess that it is becoming a haven for some cetacean populations that are being ousted from more western Mediterranean seas, the living conditions of which are progressively becoming unsuitable.

\section{CONFLICT OF INTEREST}

None declared.

\section{ACKNOWLEDGEMENTS}

The authors extend sincere gratitude to Vasilis Podiadis from the Department of Agriculture, Animal Production and Aquatic Environment, School of Agricultural Sciences, University of Thessaly, Volos, Greece and to Fabio Siniscalchi from the Department of Environmental Engineering, University of Padua, Italy for overseeing the
2005 acoustic survey. The authors also thank Anastasia Komnenou of ARION, Frank Dhermain of GECEM and Ayaka Öztürk of TUDAV for permission to quote data provided to MEDACES in this publication and to Toni Raga of the University of Valencia for securing such permission from CREMA and Fundaciõn Aspro Natura. Special thanks are due to all second parties who reported sightings and to IMMRAC volunteers who collected them and who helped with the recording of strandings.

During the final processing of this manuscript, the following communication has appeared: Dede A, Saad A, Fakhri M, Öztürk Bayram. Cetacean sightings in the Eastern Mediterranean Sea during the cruise in summer 2008. J Black Sea/Medit Envir 2012; 18: 49-57. It reports 9 sightings of common bottlenose dolphin (27 animals in all), 5 sightings of striped dolphin (53 animals), one sighting each of sperm whale ( 5 animals), Risso's dolphin (two animals) and common dolphin (two animals), all in the international water of the Eastern Mediterranean Sea, as well as in the Turkish, Lebanese and Syrian territorial waters. 


\section{REFERENCES}

[1] Notarbartolo di Sciara G, Birkun A Jr. Conserving whales and dolphins in the Mediterranean and Black seas. An ACCOBAMS status report. 2010. ACCOBAMS, Monaco. 212 p.

[2] Kerem D, Goffman O, Spanier E. Sighting of a single humpback dolphin (Sousa sp.) along the Mediterranean coast of Israel. Mar Mamm Sci 2001; 17: 170-1

[3] Netzeband GL, Gohl K, Hübscher CP, et al. The Levantine Basin crustal structure and origin. Tectonophysics 2006; 418: 167-88.

[4] Frantzis A, Alexiadou P, Paximadis G, Politi E, Gannier A, Corsini-Foka M. Current knowledge on the cetacean fauna of the Greek Seas. J Cetacean Res Manag 2003; 5: 219-32.

[5] Yacobi YZ, Zohary T, Kress et al. Chlorophyll distribution throughout the southeastern Mediterranean in relation to the physical structure of the water mass. J Mar Syst 1995; 6: 179-90.

[6] Herut B, Almogi-Labin A, Jannink NT, Gertman I. The seasonal dynamics of nutrient and chlorophyll a concentrations on the SE Mediterranean shelf-slope. Oceanol Acta 2000; 23: 771-82.

[7] McCall JM. Primary production and marine fisheries associated with the Nile outflow. Earth \& Environ 2008; 3: 179-208.

[8] Cartes JE, Maynou F, Fanelli E. Nile damming as plausible cause of extinction and drop in abundance of deep-sea shrimp in the western Mediterranean over broad spatial scales. (Article in Press): (Prog Oceanogr 2011; doi:10.1016/j.pocean.2011.01.004.

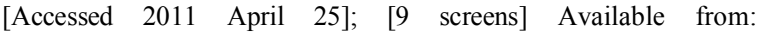
http://www.sciencedirect.com/science?_ob=MImg\&_imagekey=B6 V7B-5241F9W-1-1\& cdi $=5838 \&$ user $=1805475 \&$ pii $=$ 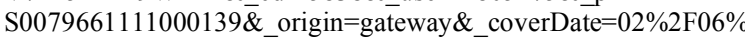 $2 \mathrm{~F} 2011 \&$ sk $=999999999 \& v i e w=\mathrm{c} \& w \mathrm{wh}=\mathrm{dGLbVzW}$ zSkzk\&md5=a1a382fcc275e177d2343c997714a605\&ie=/sdarticle. pdf

[9] Almagor G, Hall JK. Morphology of the Mediterranean continental margin of Israel (A compilative summary and a bathymetric chart). Geol Surv Isr Bull 1984; 77: 1-31.

[10] Zvieli D, Kit, Klein, M. Longshore sand transport estimates along the Mediterranean coast of Israel in the Holocene. Mar Geol 2007; 238: 61-73.

[11] Hyams-Kaphzan O, Almogi-Labin A, Sivan D, Benjamini C. Benthic foraminifera assemblage change along the southeastern Mediterranean inner shelf due to fall-off of Nile-derived siliciclastics. N Jb Geol Paläont Abh 2008; 248: 315-44.

[12] Goffman O, Roditi M, Shariv T, Spanier E, Kerem D. Cetaceans from the Israeli coast of the Mediterranean Sea. Isr J Zool 2000; 46: 143-7.

[13] Heyning JE, Perrin FW. Evidence of two species of common dolphin (genus Delphinus) from the eastern North Pacific. Natural History Museum of Los Angeles County. Contrib Sci 1994; 422: 135 .

[14] Buckland ST, Anderson DR, Burnham KP, Laak, JL, Borchers DL, Thomas L. Eds. Advanced Distance Sampling. Oxford: Oxford University Press 2004.

[15] Boisseau O, Lacey C, Lewis T, Moscrop A, Danbolt M, Mclanaghan R. Encounter rates of cetaceans in the Mediterranean Sea and contiguous Atlantic area. J Mar Biol Assoc UK 2010; 90: 1589-99.

[16] Pastene LA, Goto M, Zerbini AN, et al. Radiation and speciation of pelagic organisms during periods of global warming: the case of the common minke whale, Balaenoptera acutorostrata. Molec Ecol 2007; 16: 1481-95.

[17] Kitchener DJ, Ross JGB, Kaputi N. Variation in skull and external morphology in the false killer whale, Pseudorca crassidens, from Australia, Scotland and South Africa. Mammalia 1990; 54: 119-35.

[18] Por FD. Lessepsian migration. Berlin: Springer-Verlag 1978

[19] Spanier E, Galil BS. Lessepsian migration: a continuous biogeographical process. Endeavour, New Series 1991; 15: 102-6.

[20] Belmaker J, Brokovich E, China V, Golani D, Kiflawi M. Estimating the rate of biological introductions: lessepsian fishes in the Mediterranean. Ecology 2009; 90: 1134-41

[21] Marchessaux D. A review of the current knowledge of the cetaceans in the Eastern Mediterranean Sea. Vie Mar 1980; 2: 5966.

[22] Beadon JJ. A note on cetaceans seen and live-captured in the Gulf of Aqaba and the Gulf of Suez, 15 September 1980 through 1 September 1981. UNEP Mar Mamm Tech Rep 1991; 3: 111-14.

[23] Jefferson TA, Karczmarski L. Sousa chinensis. Mamm Sp 2001; 655: $1-9$.
[24] Feingold D. Combining cetacean watching and dive safaris as an eco-touristic project in the Red Sea. Thesis submitted in partial requirements for the Master's degree. Israel: University of Haifa 2006.

[25] Notarbartolo di Sciara G, Hanafy MH, Fouda MM, Afifi A, Costa M. Spinner dolphin (Stenella longirostris) resting habitat in Samadai Reef (Egypt, Red Sea) protected through tourism management. J Mar Biol Assoc UK 2009; 89: 211-6.

[26] Smeenk C, Addink MJ, van der Berg AB, Bosman CAW, Cadee GC. Sightings of Delphinus cf. tropicalis van Bree, 1971 in the Red Sea. Bonn Zool Beitr 1996; 46: 389-98.

[27] Baldwin R, Gallagher M, van Waerebeek K. A review of cetaceans from waters off the Arabian Peninsula. In: Fisher M, Spalton A, Gazanfar S. Eds. Oman's Natural History. Leiden: Backhuys Publishers 1999; 161-89.

[28] Jefferson TA, Van Waerebeek K. The taxonomic status of the nominal dolphin species Delphinus tropicalis Van Bree, 1971. Mar Mamm Sci 2002; 18: 787-818.

[29] Flower SS. Notes on the recent mammals of Egypt with a list of species recorded from the Kingdom. J Zool 1932; 102: 369-450.

[30] Baird RW, Schorr GS, Webster DL, McSweeney DJ, Hanson MB, Andrews RD. Movements and habitat use of satellite-tagged false killer whales around the main Hawaiian Islands. Endang Species Res 2010; 10: 107-21.

[31] Stacey PJ, Leatherwood S, Baird RW. Pseudorca crassidens. Mamm Sp 1994; 456: 1-6.

[32] Frazier J, Bertram GC, Evans PGH. Turtles and marine mammals In: Edwards AJ, Head SM, Eds. Key environments: Red Sea. Oxford: Pergamon Press 1987; 288-301.

[33] IUCN. Guidelines for application of IUCN Red List criteria at regional levels: Version 3.0. [book on the internet]. Gland, Switzerland and Cambridge, UK. IUCN Species Survival Commission 2003; [Accessed 2011 January 25] Available from: http://data.iucn.org/dbtw-wpd/edocs/2003-033-EN.pdf

[34] Natoli A, Birkun A, Aguilar A, Lopez A, Hoelzel AR. Habitat structure and the dispersal of male and female bottlenose dolphins (Tursiops truncatus). Proc Biol Sci 2005; 272: 1217-26.

[35] Viaud-Martinez KA, Brownell RL Jr, Komnenou A, Bohonak AJ. Genetic isolation and morphological divergence of Black Sea bottlenose dolphins. Biol Conserv 2008; 141: 1600-11.

[36] Öztürk B, Öztürk AA. Cetacean strandings in the Aegean and Mediterranean coasts of Turkey. Rapp Comm Int Mer Médit 1998; 35: 476-77.

[37] Gonzalvo J, Bearzi G. Action Plan for the conservation of cetaceans in Syria. Regional Activity Centre for Specially Protected Areas, Contract 39/2007-RAC/SPA; 2008;

[38] Abd Rabou AFN, Yassin MM, Al Agha MR, Hamad DM, Ali AKS. Wild mammals in the Gaza Strip, with particular reference to Wadi Gaza. Islam Univ J (Series of Natural Studies and Engineering) 2007; 15: 87-109.

[39] Gaspari S, Azzellino A, Airoldi S, Hoelzel R. Social kin associations and genetic structuring of striped dolphin populations (Stenella coeruleoalba) in the Mediterranean Sea. Mol Ecol 2007; 16: 2922-33.

[40] Kinzelbach R. A record of striped dolphin Stenella coeruleoalba (Meyen, 1833) from the Turkish Mediterranean sea coast. Zool Middle East 1997; 15: 15-8.

[41] Öztürk B, Salman A, Öztürk AA, Tonay A. Cephalopod remains in the diet of striped dolphins (Stenella coeruleoalba) and Risso's dolphins (Grampus griseus) in the eastern Mediterranean Sea. Vie Milieu 2007; 57: 53-9.

[42] Fortuna CM, Canese S, Giusti M, et al. An insight into the status of the striped dolphins, Stenella coeruleoalba, of the southern Tyrrhenian Sea. J Mar Biol Assoc UK 2007; 87: 1321-6.

[43] Forcada J, Hammond P. Geographical variation in abundance of striped and common dolphins of the western Mediterranean. J Sea Res 1998; 39: 313-25.

[44] Laran S, Drouot-Dulau V. Seasonal variation of striped dolphins, fin- and sperm whales' abundance in the Ligurian Sea (Mediterranean Sea). J Mar Biol Assoc UK 2007; 87: 345-52.

[45] Lauriano G, Panigada S, Canneri R, Zeichen M, Notarbartolo-Di Sciara G. Abundance estimate of striped dolphins (Stenella coeruleoalba) in the Pelagos Sanctuary (NW Mediterranean Sea) by means of line transect survey. J Cetacean Res Manag 2010; 11: 279-83. 
[46] Gaspari S. Social and population structure of striped and Risso's dolphins in the Mediterranean Sea. Ph.D Thesis, UK: University of Durham 2004; 22-48.

[47] Go'mez de Segura A, Crespo EA, Pedraza SN, Hammond PS, Raga JA. Abundance of small cetaceans in waters of the central Spanish Mediterranean. Mar Biol 2006; 150: 149-60.

[48] Gordon JCD, Matthews JN, Panigada S, Gannier A, Borsani JF, Notarbartolo Di SG. Distribution and relative abundance of striped dolphins, and distribution of sperm whales in the Ligurian Sea cetacean sanctuary: results from a collaboration using acoustic monitoring techniques. J Cetacean Res Manage 2000; 2: 27-36.

[49] Natoli A, Caňadas A, Vaquero C, Politi E, Fernandez-Navarro P, Hoelzel AR. Conservation genetics of the short-beaked common dolphin (Delphinus delphis) in the Mediterranean Sea and in the eastern North Atlantic Ocean. Conserv Genet 2008; 9 :1479-87.

[50] Bodenheimer FS. Animal and man in bible lands. Collection de Travaux de l'Académie Internationale d'Histoire des Sciences, No 10. Leiden: E.J. Brill; 1960.

[51] Bearzi G, Reeves RR, Notarbartolo di Sciara G, et al. Ecology, status and conservation of short-beaked common dolphins, Delphinus delphis in the Mediterranean Sea. Mamm Rev 2003; 33: 224-52.

[52] Agazzi S, Bearzi G, Politi E. Short-beaked common dolphin prey species in the Eastern Ionian Sea: insight from fish scales sampled during surface foraging. Eur Res Cetacean 2004; 15: 351-3

[53] Cañadas A. Towards conservation of dolphins in the Alborán Sea. $\mathrm{PhD}$ thesis, Universidad Autónoma de Madrid, Spain; 2006.

[54] Bearzi G, Reeves RR, Remonatoa E, Pierantonioa N, Airoldi S. Risso's dolphin Grampus griseus in the Mediterranean Sea. (Article in Press): Mammal Biol 2010; doi:10.1016/j.mambio.2010.06.003. [Accessed 2010 July 25]; [18 screens] Available from: http://www.dolphinbiology.org/_download/literature/Bearzi_etal_2 010_MammalBiol.pdf

[55] Praca E, Gannier A, Ecological niche of three teuthophageous odontocetes in the northwestern Mediterranean Sea. Ocean Sci 2007; 4: 785-815.

[56] Gaspari S, Airoldi S, Hoelzel AR. Risso's dolphins (Grampus griseus) in UK waters are differentiated from a population in the Mediterranean Sea and genetically less diverse. Conserv Genet 2007; 8: 727-32.

[57] Öztürk AA, Tonay AM, Dede A. Strandings of the beaked whales, Risso's dolphins, and a minke whale on the Turkish coast of the Eastern Mediterranean Sea. J Black Sea/Med Environ 2011; 17: 26974.

[58] MEDACES [homepage on the Internet]. Mar Zoology Unit, University of Valencia; [updated 2011 March 3; cited 2011 April 15]. Available from: http://medaces.uv.es/

[59] Watkins WA, Tyack P, Moore KE, Notarbartolo di Sciara G. Steno bredanensis in the Mediterranean Sea. Mar Mamm Sci 1987; 3: 7882

[60] Jefferson TA. Rough-toothed dolphin Steno bredanensis. In: Perrin W, Wursig B, Thewissen JGM. Eds. Encyclopaedia of marine mammals. New York: Academic Press 2002; 1055-9.

[61] Barlow J, Gisiner R. Mitigating, monitoring and assessing the effects of anthropogenic sound on beaked whales. J Cetacean Res Manag 2006; 7: 239-49.

[62] Dalebout ML, Robertson KM, Frantzis A, et al. Worldwide structure of mtDNA diversity among Cuvier's beaked whales (Ziphius cavirostris): implications for threatened populations. Mol Ecol 2005; 14: 3353-71.

[63] Aharoni I. Animals hitherto unknown to or little known from Palestine. Bull Zool Soc Egypt 1944; 6: 40-1.

[64] Kinzelbach R. Der Cuvier-schnabelwal (Ziphius cavirostris) im östlichen Mittelmeer. Z. Säuget 1985; 50: 314-6.

[65] Podestá M, D’Amico A, Pavan G, Drougas A, Komnenou A, Portunato N. A review of Cuvier's beaked whale strandings in the Mediterranean Sea. J Cetacean Res Manag 2006; 7: 251-61.

[66] Cañadas A, Sagarminaga R, de Stephanis R, Urquiola E, Hammond PS. Habitat selection models as a conservation tool: proposal of marine protected areas for cetaceans in Southern Spain. Aquat Conserv: Mar Fresh Ecosyst 2005; 15: 495-521.

[67] Holcer D, Notarbartolo di Sciara G, Fortuna CM, Lazar $\mathrm{B}$, Onofri V. Occurrence of Cuvier's beaked whales in the southern Adriatic Sea: evidence of an important Mediterranean habitat. J Mar Biol Assoc UK 2007; 87: 359-62.

[68] Barlow J. Trackline detection probability for long-diving whales. In: Garner GW, Amstrup SC, Laake JL, Manly BFJ, McDonald LL, Robertson DG. Eds. Marine mammal survey and assessment methods. Rotterdam: Balkema 1999; 209-21.

[69] Morrissey RP, Ward J, DiMarzio N, Jarvis S, Moretti DJ. Passive acoustic detection and localization of sperm whales (Physeter macrocephalus) in the tongue of the ocean. Appl Acoust 2006; 67: 1091-105.

[70] Engelhaupt D, Hoelzel AR, Nicholson C, et al. Female philopatry in coastal basins and male dispersion across the North Atlantic in a highly mobile marine species, the sperm whale (Physeter macrocephalus). Mol Ecol 2009; 18: 4193-205.

[71] Notarbartolo di Sciara G, Zanardelli M, Jahoda M, Panigada S, Airoldi S. The fin whale Balaenoptera physalus (L. 1758) in the Mediterranean Sea. Mamm Rev 2003; 33: 105-50.

[72] Mendelssohn H, Yom-Tov Y. In: Alon A. Ed. Plants and animals of the land of Israel - An illustrated encyclopedia; Vol 7: Mammals. Tel Aviv: Ministry of Defense Publishing House 1987; 156-8 (in Hebrew)

[73] Spanier E. Whales on Israel's Coasts? Isr Land Nat 1981; 7(1): 32 3.

[74] Orsi Relini L. The cetacean sanctuary in the Ligurian Sea: a further reason. Biol Mar Medit 2000; 7: 117-26.

[75] Bérubé M, Aguilar A, Dendanto, et al. Population genetic structure of North Atlantic, Mediterranean Sea and Sea of Cortez fin whales, Balaenoptera physalus (Linnaeus, 1758); analysis of mitochondrial and nuclear loci. Mol Ecol 1998; 7: 585-99.

[76] Perrin WF, Brownell RL. Minke whales Balaenoptera acutorostrata and Balaenoptera bonaerensis. In: Perrin WF, Wursig B, Thewissen JGM. Eds. Encyclopedia of marine mammals. New York: Academic Press 2002; pp. 750-4

[77] Wassif K. Pseudorca crassidens Owen from Mediterranean shores of Egypt. J Mammal 1956; 37: 456.

[78] Mörzer Bruyns WFJ. Sight records and notes on the false killer whale. Saugetier Mitteil 1969; 17: 351-6.

[79] Weir CR. Occurrence and distribution of cetaceans off northern Angola, 2004/05. J Cetacean Res Manag 2007; 9: 225-39.

[80] Leatherwood S, McDonald D, Baird RW, Scott MD. The false killer whale Pseudorca crassidens (Owen, 1846). A summary of information available through 1989. Oceans Unlimited 1989; Tech. Report 89-001.

[81] Duguy R, Casinos A, Di Natale A, et al. Repartition et fréquences des mammifères marins en Méditerranée. Rapp Comm Int Mer Médit 1983; $28: 223-30$.

[82] Cagnolaro L, Magnaghi L, Podestà M, Jann B. False killer whale Pseudorca crassidens - a rare stranding for the Italian coast. Europ Res Cetac 1989; 3: 65-6.

[83] Podestà M, Cagnolaro L, Cozzi B. First record of a stranded Gervais' beaked whale, Mesoplodon europaeus (Gervais, 1855) in the Mediterranean waters. Atti della Societa Italiana di Scienze Naturale del Musco Civico di Storia Naturale di Milano 2005; 146(1): 109-16.

[84] Scheinin AP, Kerem D, Macleod CD, Gazo M, Chicote CA, Castellote M. Gray whale (Eschrichtius robustus) in the Mediterranean Sea: anomalous event or early sign of climatedriven distribution change? Published online: Mar Biodivers Rec 2011; 4 e28. [Accessed 2011 May 25]; [5 screens] Available from: http://journals.cambridge.org/action/displayAbstract?fromPage $=$ onl ine \&aid $=8258736$

[85] Kasparek M. The false killer whale, Pseudorca crassidens (Cetacea: Delphinidae), new for Syria. Zool Middle East 1997; 14: 23-6. 